NATIONAL LABORATORY

MANAGED BY UT-BATTELLE

FOR THE DEPARTMENT OF ENERGY

\title{
Moisture Performance of Sealed Attics in the Mixed-Humid Climate
}

\section{December 2013}

Updated February 2014

\section{Prepared by \\ Philip Boudreaux \\ Simon Pallin \\ Roderick Jackson}

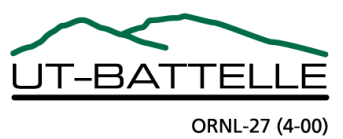




\section{DOCUMENT AVAILABILITY}

Reports produced after January 1, 1996, are generally available free via US Department of Energy (DOE) SciTech Connect.

Website http://www.osti.gov/scitech/

Reports produced before January 1, 1996, may be purchased by members of the public from the following source:

National Technical Information Service

5285 Port Royal Road

Springfield, VA 22161

Telephone 703-605-6000 (1-800-553-6847)

TDD 703-487-4639

Fax 703-605-6900

E-mail info@ntis.gov

Website http://www.ntis.gov/support/ordernowabout.htm

Reports are available to DOE employees, DOE contractors, Energy Technology Data Exchange representatives, and International Nuclear Information System representatives from the following source:

Office of Scientific and Technical Information

PO Box 62

Oak Ridge, TN 37831

Telephone 865-576-8401

Fax 865-576-5728

E-mail reports@osti.gov

Website http://www.osti.gov/contact.html

This report was prepared as an account of work sponsored by an agency of the United States Government. Neither the United States Government nor any agency thereof, nor any of their employees, makes any warranty, express or implied, or assumes any legal liability or responsibility for the accuracy, completeness, or usefulness of any information, apparatus, product, or process disclosed, or represents that its use would not infringe privately owned rights. Reference herein to any specific commercial product, process, or service by trade name, trademark, manufacturer, or otherwise, does not necessarily constitute or imply its endorsement, recommendation, or favoring by the United States Government or any agency thereof. The views and opinions of authors expressed herein do not necessarily state or reflect those of the United States Government or any agency thereof. 


\title{
MOISTURE PERFORMANCE OF SEALED ATTICS IN THE MIXED- HUMID CLIMATE
}

\author{
Philip Boudreaux \\ Simon Pallin \\ Roderick Jackson
}

Date Published: December 2013

\author{
Prepared by \\ OAK RIDGE NATIONAL LABORATORY \\ Oak Ridge, Tennessee 37831-6283 \\ managed by \\ UT-BATTELLE, LLC \\ for the \\ US DEPARTMENT OF ENERGY \\ under contract DE-AC05-00OR22725
}





\section{CONTENTS}

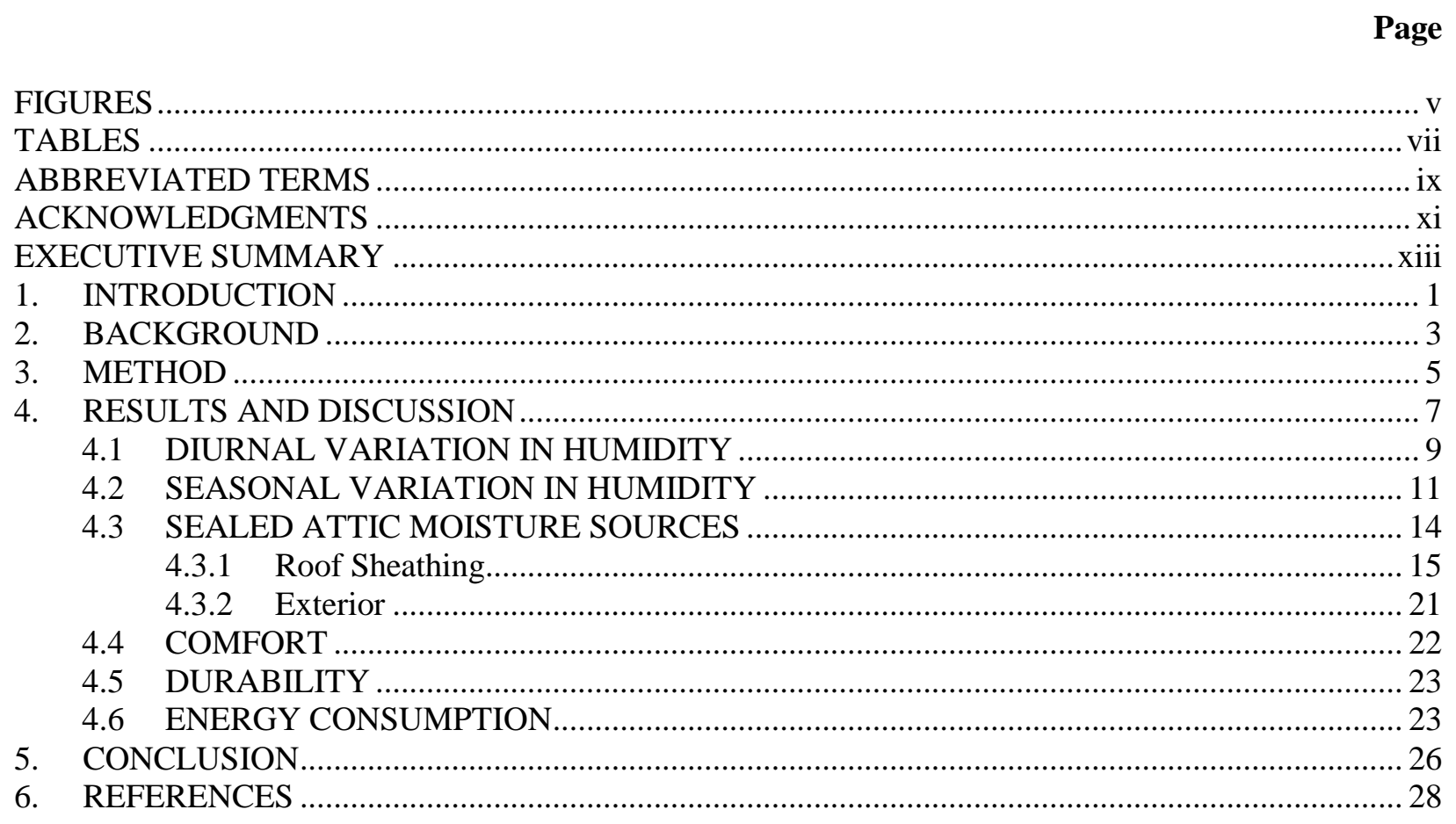





\section{FIGURES}

Figures

Page

1 Calendar of different heat pump systems operating at each unoccupied research home. 3 Temperature and relative humidity measurement locations on the south side of the retrofit home attic.

Average monthly absolute humidity in sealed attics (red) compared with that of vented attics (blue).

Average monthly absolute humidity measured in the interior of sealed attic homes (red) compared to vented attic homes (blue).

The monthly average interior moisture levels for each home in the study between January 2012 and September 2012 (red: sealed; blue: vented).

Partial pressure of water vapor $\left(\mathrm{p}_{\mathrm{v}}\right)$ at measurement locations throughout the attic and interior of the sealed attic home for three sunny summer days.

Actual vapor flows in the sealed attic home.

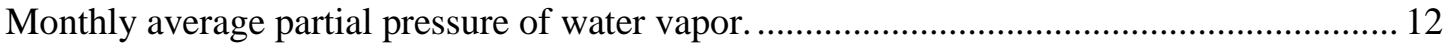

Actual vapor flows in the sealed attic home.

Moisture content of the north roof sheathing

Potential water and vapor transportation mechanisms and locations in an attic and roof..Error! Bookmark no There are four essential steps for solar-driven water vapor diffusion in asphalt shingle roofs.

An illustration of the suction height, $H$, and the width between the shingle sheets, $d$. The adhesive strip between the shingle sheets is likely to prevent capillary suction of water into the interface of the shingles because the required maximum width, $d$, is likely to be exceeded.

A two-dimensional model was created in WUFI® 2D to simulate an asphalt shingle roof assembly.

The annual variation in relative humidity of the air layer underneath the shingles with and without an assumed constantly saturated shingles interface.

The annual variation of moisture content in the wood sheathing with and without an available moisture source between the shingle laps.

Monthly average absolute humidity in the sealed attics compared with the outside humidity.

Monthly average relative humidity for the interior of the retrofit home (sealed attic) compared to the builder home (vented attic)...... 



\section{TABLES}

Tables $\quad$ Page

1 Envelope leakage and mechanical ventilation at each unoccupied research home .................. 3

2 Occupancy, floor area, occupant density, infiltration, and attic details for all homes

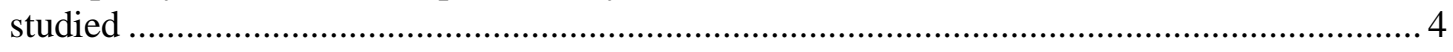

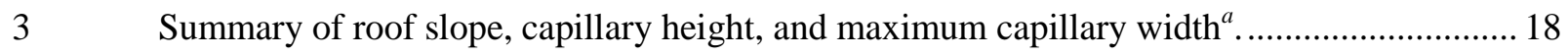





\section{ABBREVIATED TERMS}

$\mathrm{ACH} \quad$ air change per hour

CARB Consortium of Advanced Residential Buildings

HVAC heating, ventilation, and air conditioning

LBL Lawrence Berkeley National Laboratory

M.C. moisture content

ORNL Oak Ridge National Laboratory

OSB oriented strand board

$\mathrm{p}_{\mathrm{v}} \quad$ partial pressure of water vapor

SHR sensible heat ratio

TMY typical meteorological year 



\section{ACKNOWLEDGMENTS}

The authors would like to thank David Dinse, from the Tennessee Valley Authority, for allowing us use of the three unoccupied research homes for this work. We also thank Manfred Kehrer for help with WUFI analysis and lending his moisture expertise to the project. Thanks are also due to Philip Childs for completing the sorption isotherm and permeance measurements of open- and closed-cell foam samples taken from the research house attic. We also want to thank Jeffery Munk for using his expertise in HVAC systems in helping us understand the operation of the units installed at the research homes. Thanks also go to Anthony Gehl for installing sensors in the research homes when needed. Thanks to William Miller and Andre Desjarlais for engaging in long discussions concerning sealed attics and their behavior. Also thanks to Mikael Salonvaara, from Owens Corning, for the blower door tests he completed at the retrofit home. We would also like to thank Kohta Ueno and Armin Rudd, from Building Science Corporation, for input they had to the project. Lastly we thank Iain Walker and William Miller for reviewing this paper. 



\section{EXECUTIVE SUMMARY}

Oak Ridge National Laboratory studied 8 homes in the mixed-humid climate, 4 with vented attics and 4 with sealed attics. ORNL wanted to understand the moisture performance of the sealed attic and how it affected the interior environment. We found that the attic and interior of the four sealed attic homes on average were more humid than the attic and interior observed in the four vented attic homes. This can be attributed in part to the fact that sealed attics reduce sensible cooling loads in the home without impacting internal sources of moisture generation (e.g. cooking, showers, etc). Therefore, the sensible heat ratio (SHR) in the home is decreased. If this SHR is much lower than the equipment SHR, then higher interior moisture levels in the sealed attic home could result if no additional moisture mitigation measure is taken. Additionally, excess moisture that enters a vented attic can be removed via vents. However, this drying mechanism is hindered in the sealed attic because the soffit, gable, and ridge vents have been sealed with foam, thereby minimizing ventilation to the exterior. This effect also further decreases the home's SHR in the mixed-humid climate sealed attic home.

An extensive analysis of a simulated-occupancy laboratory home with an unvented attic was conducted to better assess the infiltration and exfiltration of attic moisture. Because solar driven moisture through the roof deck is often speculated as a source of moisture infiltration, physics-based analysis was used to elucidate this phenomenon and to suggest it provides a very limited, if any at all, contribution to the moisture level in the home.

Multiple approaches exist to mitigate higher moisture levels in attics, which include providing conditioned air to the attic. Because the laboratory home had a variable speed HVAC system with the ability to adjust the equipment sensible heat ratio (SHR) closer to the building's (SHR), the higher moisture level in the home was reduced by controlling the humidity. This approach resulted in a 7\% increase in cooling energy consumption. Such mechanisms to control humidity should be considered when evaluating the cost effectiveness of the sealed attic design as a solution for bringing ducts into a semi-conditioned space. Other alternatives to bringing ducts into the conditioned space in both new construction and retrofit work in the mixed-humid climate should also be evaluated and compared, when determining the best solution.

Despite the elevated attic and interior moisture in the sealed attic homes, no mold or material degradation has been found to date. The roof sheathing moisture content has stayed below 20\%, indicating low potential for material degradation. Also, the relative humidity at the roof sheathing has stayed within the ASHRAE 160 design criteria except for a short time during the 2011/2012 winter. This was due to the duct work not being operated in the attic which usually provides a dehumidification pathway. 



\section{INTRODUCTION}

Oak Ridge National Laboratory (ORNL) investigated the moisture performance of unvented (sealed) attics in the mixed-humid climate. ORNL had the opportunity to study eight homes, four with sealed attics and four with vented attics. There has been anecdotal evidence of sealed attics leading to roof deck degradation in other humid climates, such as Florida and South East Texas. Cases of high moisture in sealed attics are documented on line on energy and building blogs and websites (GBA 2010, JLC 2010). Furthermore, researchers at Florida Solar Energy Commission have documented high moisture levels in sealed attics in Florida (Colon 2011). The Consortium of Advanced Residential Buildings (CARB) saw higher relative humidity in unvented attics than in vented attics in a dry climate (Aldrich et al. 2010). Historically, attics were vented to improve the moisture performance of the home. A brief history of vented attics with an introduction to the sealed attic concept follows.

William Rose outlines the history of attic ventilation in his reports Early History of Attic Ventilation and The History of Attic Ventilation Regulation and Research (Rose 1995a, 1995b). Rose states that, in traditional construction, roofs had holes, and the holes provided ventilation, making the house itself a chimney. This ventilation provided cooling as well as the exhausting of odors and contaminants. By the early 1900s, homes were being built with more airtight roofs, which did not allow much ventilation. As insulation infiltrated the housing industry in the 1930s, homes with attic floor insulation had paint peeling on the interior wall, which suggested high relative humidity. It was during this time that the intentional venting of attics was put forth as a means for condensation control. By the 1970s, manufacturers of ridge vents sold their products under the notion that venting of attics in hot climates would decrease the temperature of the attic and thus would decrease the cooling load of the home.

Beginning in 1996, the U.S. Department of Energy (DOE) led research and testing of a sealed attic concept. The concept was designed to decrease the conductive and convective energy losses from the space-conditioning equipment located in the attic. When the insulation is moved from the attic floor to the attic ceiling, the attic temperatures usually stay within $10^{\circ} \mathrm{F}$ of the interior temperature, so there is a significant decrease in conductive energy loses from the ductwork to the attic. Furthermore, the sealed attic decreases the air infiltration of the whole home because the air/thermal boundary is moved from the leaky attic floor to the less-leaky roof (after foam is applied). With this design, less conditioned air is lost to the outside. The sealed attic design is expected to save $10 \%$ in space conditioning energy when ducts are in the attic compared to a vented attic (Rudd et al. 1999, DOE 2013a). The sealed, unvented, conditioned, or cathedralized attic as they are sometimes called has been part of the International Residential Code since 2006 (DOE 2013a).

From a thermal perspective, the sealed attic performs very well; however, there are still questions concerning how best to design a sealed attic from a moisture perspective, especially in humid climates. This work compares four sealed attic homes to four vented attic homes to determine the moisture performance of sealed attics in the mixed-humid climates and how this energy conservation measure affects the comfort, durability, and energy consumption of the home. While this is not a sample size large enough to be statistically significant, it is sufficient to provide insight into specific trends. 



\section{BACKGROUND}

Of the eight homes in this study, three were unoccupied test houses and five were occupied homes that had recently had energy retrofit packages installed. All homes were in the mixed-humid climate. There were two unoccupied vented attic homes and one unoccupied sealed attic home. The first vented attic home, called the "builder home," was IECC 2006 code compliant with a vented attic design with R-26 fiberglass insulation on the attic floor. The second vented attic home, called the "high-performance home," had a vented attic with a radiant barrier under the roof deck and R-50 fiberglass insulation on the attic floor. The sealed attic home, called the "retrofit home," had an unvented attic with R-30 underneath the roof deck both insulating and air-sealing the attic roof. The sealed attic had 1 in. of closed-cell foam under the roof deck, then about $5.5 \mathrm{in}$. of open-cell foam, and then 1 to $2 \mathrm{in}$. of blown fiberglass insulation called Spider®. Over time much of the fiberglass fell to the attic floor. All homes had similar construction above the oriented strand board (OSB) roof deck (15 lb felt paper and asphalt shingles). The heating and cooling systems were also different in the unoccupied homes and were changed throughout the lifetime of the homes. A graphic describing the different systems is shown in Fig. 1. The envelope leakage and mechanical ventilation in each home is summarized in Table 1 . To calculate the combined ventilation, we converted the envelope leakage [in air changes per hour $(\mathrm{ACH})$ ] at $\mathrm{ACH}_{50}$ to $\mathrm{ACH}$ natural using the Lawrence Berkeley Laboratory $(\mathrm{LBL})$ " $\mathrm{N}$ " factors $(\mathrm{N}$ factor $=21.5$ and height factor $=0.81)$, and we converted the mechanical ventilation to $\mathrm{ACH}$ natural by converting to cubic feet per hour then dividing by the house volume, which was $23,235 \mathrm{ft}^{3}$ (BPI 2005). After making these conversions, we could add the envelope leakage and mechanical ventilation.

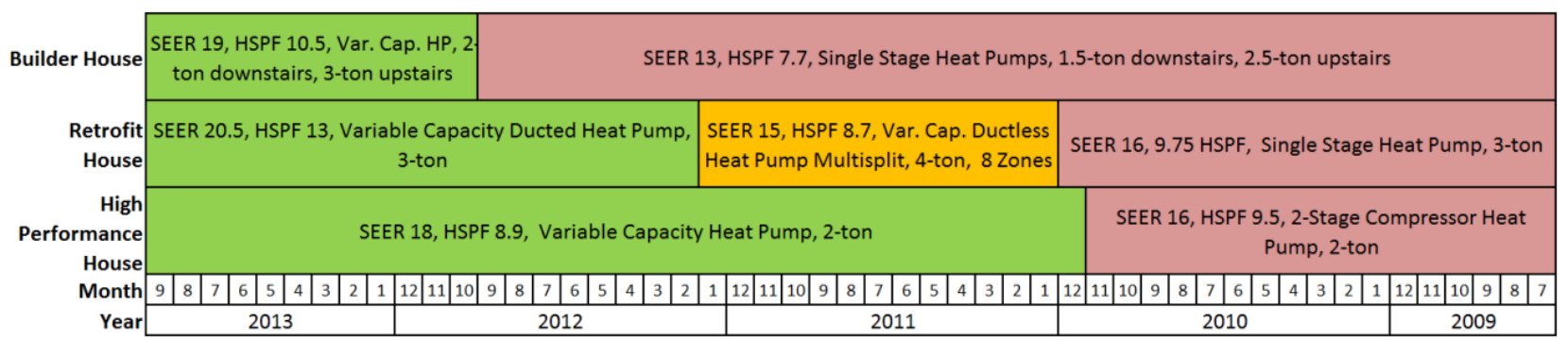

Fig. 1. Calendar of different heat pump systems operating at each unoccupied research home.

Table 1. Envelope leakage and mechanical ventilation at each unoccupied research home

\begin{tabular}{lccc}
\hline & $\begin{array}{c}\text { Envelope leakage } \\
\left(\mathbf{A C H}_{\mathbf{5 0}}\right)\end{array}$ & $\begin{array}{c}\text { Mechanical ventilation } \\
(\text { average } \mathbf{C F M})\end{array}$ & $\begin{array}{c}\text { Combined ventilation } \\
\left(\mathbf{A C H}_{\text {nat }}\right)\end{array}$ \\
\hline Builder House & 5.7 & 35 & 0.42 \\
Retrofit House & 3.5 & 42 & 0.31 \\
High-Performance House & 2.6 & 42 & 0.26 \\
\hline
\end{tabular}

The occupancy in the homes was simulated by controlling appliances such as the oven, dishwasher, television, clothes washer, and clothes dryer. Water draws to simulate the typical consumption for a three bedroom house were implemented throughout the day by automatically operating the master shower. Ceramic heaters and a humidifier were used to add the sensible and latent heat from the occupants to the space. By controlling the appliances the same in each of the homes, occupancy was no longer a variable and the homes could be compared directly to each other. For more information on the occupancy simulation, see the ASHRAE Transactions paper by Boudreaux et al. (2012a). For more information on the research homes see the report by Christian et al. (2010). 
Of the five occupied homes, three had sealed attics (Gaiter, Green, and Lakeview) and two had vented attics (Baker and Summit). For more information on these homes see the reports from ORNL (Boudreaux et al. 2012b, Jackson et al. 2012). Table 2 shows occupancy, floor area, occupant density, and infiltration and attic details for all homes studied.

Table 2. Occupancy, floor area, occupant density, infiltration, and attic details for all homes studied

\begin{tabular}{|c|c|c|c|c|c|}
\hline Test home $^{a}$ & $\begin{array}{l}\text { Number of } \\
\text { occupants }\end{array}$ & $\begin{array}{c}\text { Floor area } \\
\left(\mathbf{f t}^{2}\right)\end{array}$ & $\begin{array}{c}\text { Occupant } \\
\text { density } \\
\left(\mathrm{ft}^{2} / \text { person) }\right.\end{array}$ & $\begin{array}{c}\text { Envelope } \\
\text { infiltration } \\
\left(\mathbf{A C H}_{50}\right)\end{array}$ & Attic details ${ }^{b}$ \\
\hline Retrofit (U) & 3 & 2400 & 800 & 3.5 & $\begin{array}{c}1 \text { in. } \mathrm{CC}, 5.5 \text { in. } \\
\text { OC }\end{array}$ \\
\hline Green $(\mathbf{O})$ & 1 & 2300 & 2295 & 5.5 & 6 in. $\mathrm{CC}$ \\
\hline Gaiter (O) & 1 & 1800 & 1769 & 5.3 & $\begin{array}{l}1 \text { in. CC, } \\
8 \text { in. OC }\end{array}$ \\
\hline Lakeview (O) & 3 & 1700 & 570 & 10.1 & 6 in. $\mathrm{OC}$ \\
\hline Builder (U) & 3 & 2400 & 800 & 5.7 & Vented \\
\hline High-Performance (U) & 3 & 2400 & 800 & 2.6 & Vented \\
\hline Baker (O) & 3 & 5200 & 1700 & 6.8 & Vented \\
\hline Summit (O) & 2 & 3100 & 1600 & 3.9 & Vented \\
\hline
\end{tabular}

${ }^{a}$ O: occupied; U: unoccupied

${ }^{b}$ CC: closed cell; OC: open cell (foam) 


\section{METHOD}

Temperature and relative humidity sensors were installed throughout the eight homes. In most of the occupied homes, the temperature and relative humidity were measured in the attic and living zones and in some cases below the roof sheathing. Figure 2 shows a diagram of the sensor locations in the retrofit home attic and interior. The sensors in the foam and on the roof deck were installed roughly in the center of the roof face and in the center of a cavity between two rafters. There were sensors installed on the north and south roof. The black, orange, and green dots represent combination probes that include a Honeywell 192-103LET-AO1 that measured temperature and a Honeywell HIH-4000 that measured relative humidity. The red and brown dots in the middle of the attic and the interior represent Campbell Scientific, Inc., HMP60 temperature and relative humidity probes. For the two unoccupied vented attic homes (builder and high performance) there was no foam under the roof deck so the orange and green sensors were not available in those homes.

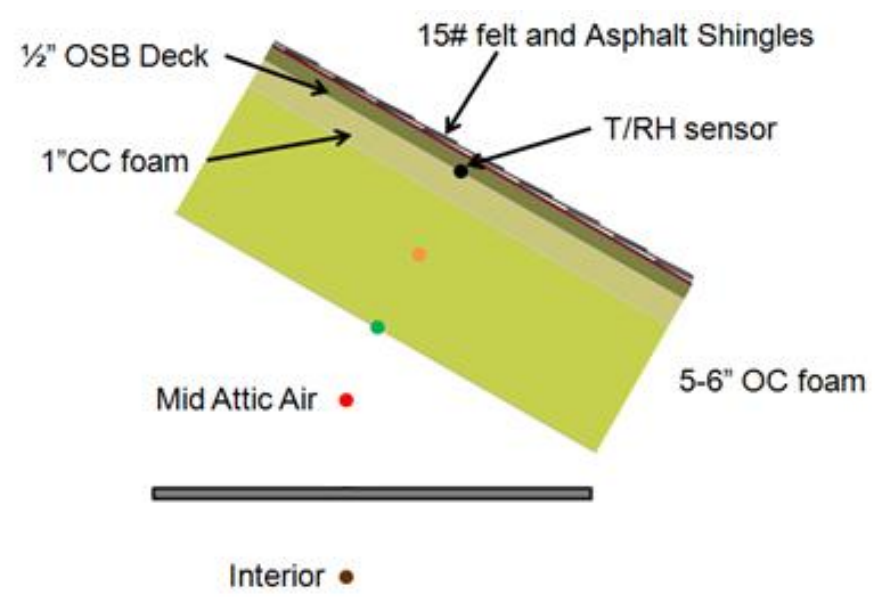

Fig. 2. Temperature and relative humidity measurement locations on the south side of the retrofit home attic and interior. The green boxes represent layers of spray foam. The grey line is the attic floor drywall.

Not shown in Fig. 2, are Ashcroft Inc. CXLdp differential pressure transducers, which measured the difference in air pressure between the attic and the interior of the house in the builder and retrofit homes.

Water vapor moves by diffusion from areas of higher concentration to areas of lower concentration. The partial pressure of water vapor $\left(\mathrm{p}_{\mathrm{v}}\right)$ is analogous to water vapor concentration. We can use these measurements with modeling software to estimate the flow of water vapor by diffusion between the roof sheathing and attic and between the attic and interior. Also, air moves from areas of high pressure to areas of low pressure. We can estimate the movement of moisture by advection (moisture transport by moist air movement only) across the ceiling plane in the retrofit home because we have determined the air flow equation as a function of the pressure difference across the ceiling plane. These two transport mechanisms of water vapor movement, by diffusion and by convection of air, will be used to gain understanding of the moisture performance of the sealed attic in the mixed-humid climate. 



\section{RESULTS AND DISCUSSION}

Before we present the diffusion and convection moisture flows, we will discuss the general trends of absolute moisture across all eight homes in this study. Figure 3 compares the monthly average $p_{v}$ in the sealed attic homes with those of the vented attic homes for the time period where data are available for all eight homes. Each bar is the monthly average of water vapor concentration for either the four sealed attics (red bars) or the four vented attics (blue bars). As shown in Fig. 3, the sealed attics are more humid than the vented attics.

Figure 4 compares the interior moisture levels in the four homes with a sealed attic to the four homes with a vented attic. The averages are higher in the sealed attic homes, but the error bars overlap for every month. This suggests that the effect of the sealed attic on the interior moisture levels of a home depend highly on the characteristics of the home. Variables such as occupant density, infiltration, and thermostat schedule can all affect the interior moisture levels. Figure 5 breaks Fig. 4 into each home in the study. Two of the sealed attic homes, Green and Lakeview, have the highest summer humidity. Lakeview had the highest occupant density and the highest infiltration (see Table 2), which could both contribute to higher interior moisture. Green had the highest average monthly temperature inside the home at $84^{\circ} \mathrm{F}$ during July 2012. The homeowner set the thermostat high while the occupants were gone (most of the month), which would decrease the heating, ventilation, and air-conditioning (HVAC) run time and would thereby reduce moisture removal.

In the rest of the discussion, the diurnal and seasonal variation of vapor movement, the sealed attic moisture sources, and the impact of a sealed attic on comfort, durability, and energy consumption will be presented.

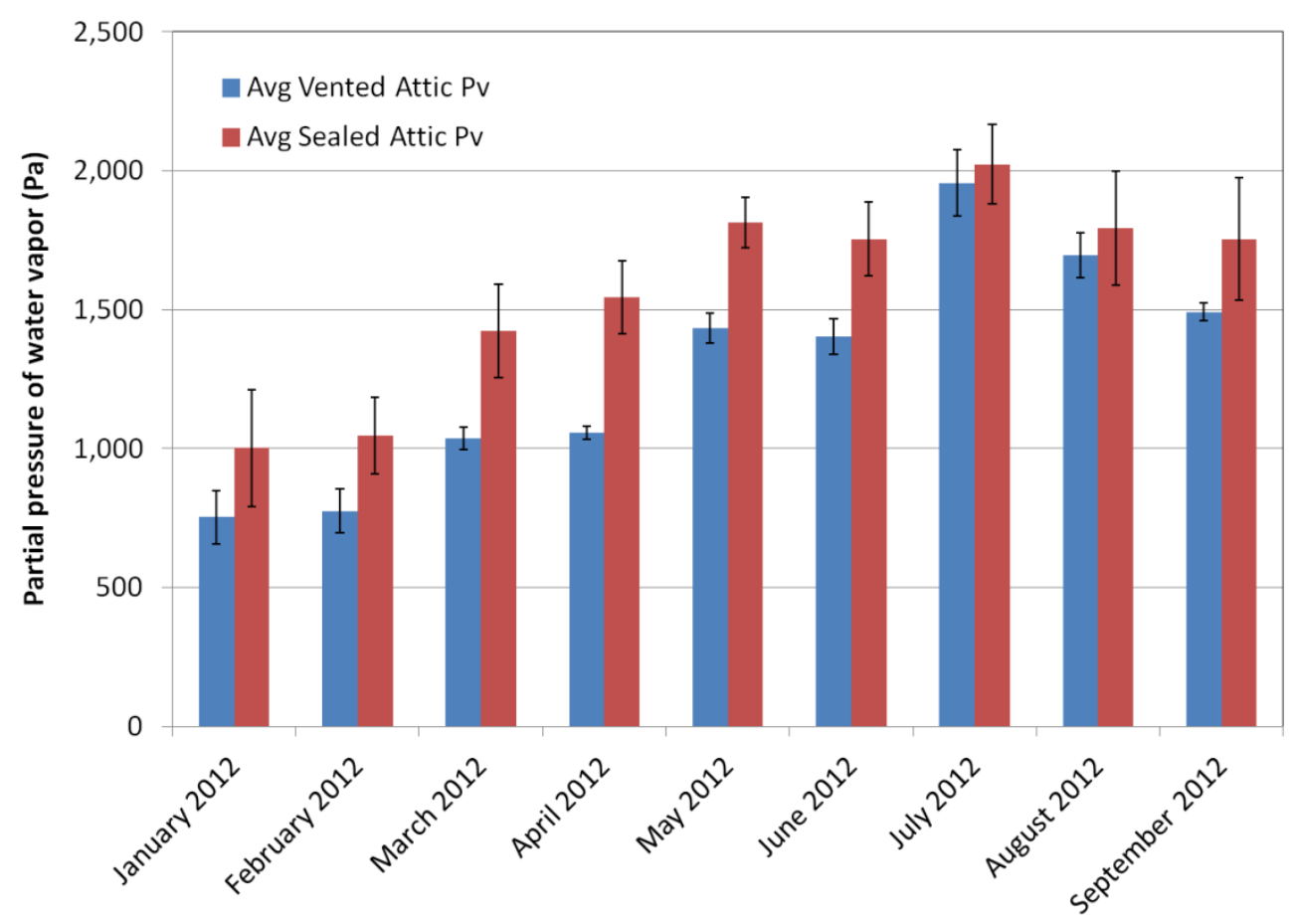

Fig. 3. Average monthly absolute humidity in sealed attics (red) compared with that of vented attics (blue). The error bars are the standard deviation of the average. 


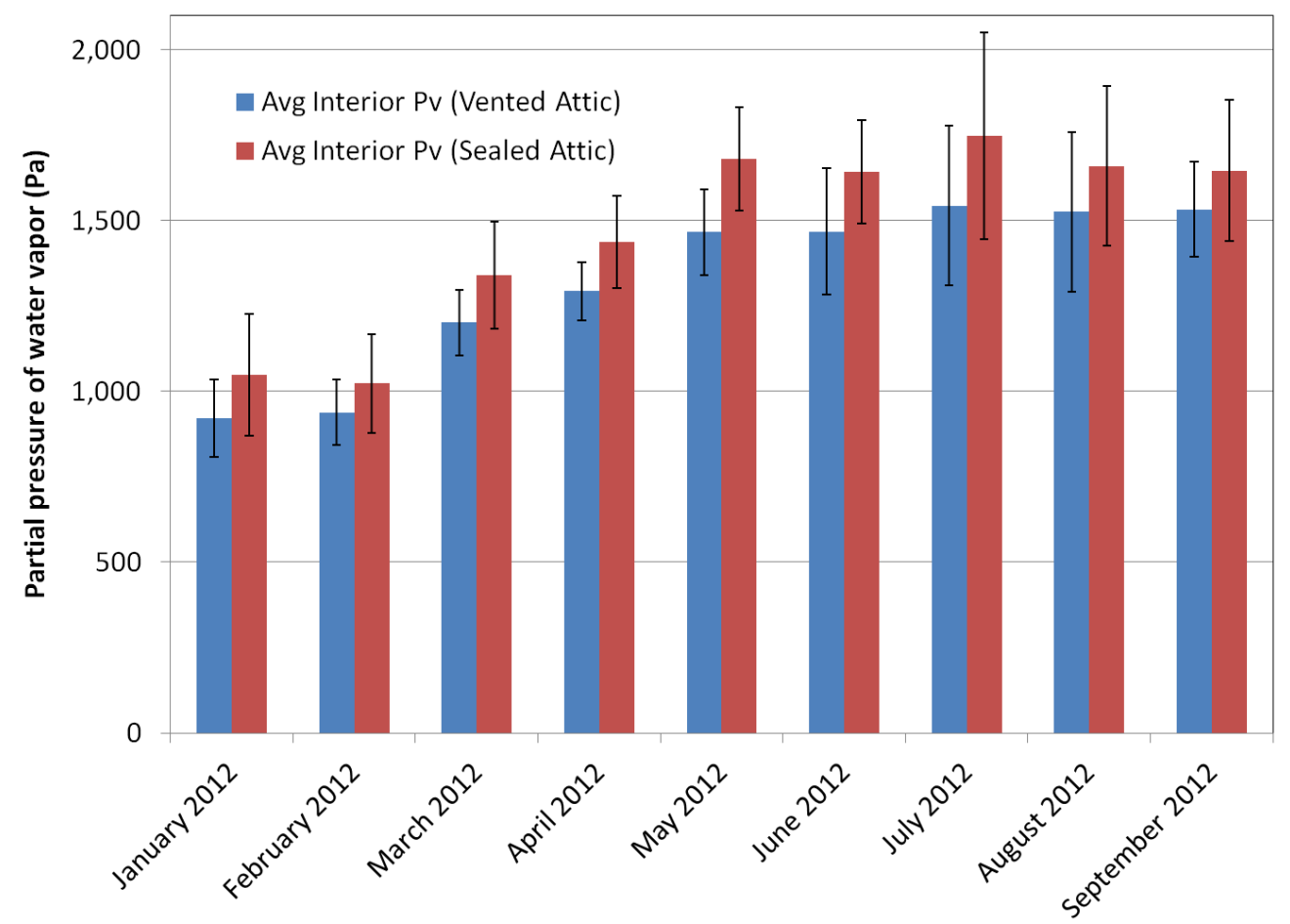

Fig. 4. Average monthly absolute humidity measured in the interior of sealed attic homes (red) compared to vented attic homes (blue). The error bars are the standard deviation of the average.

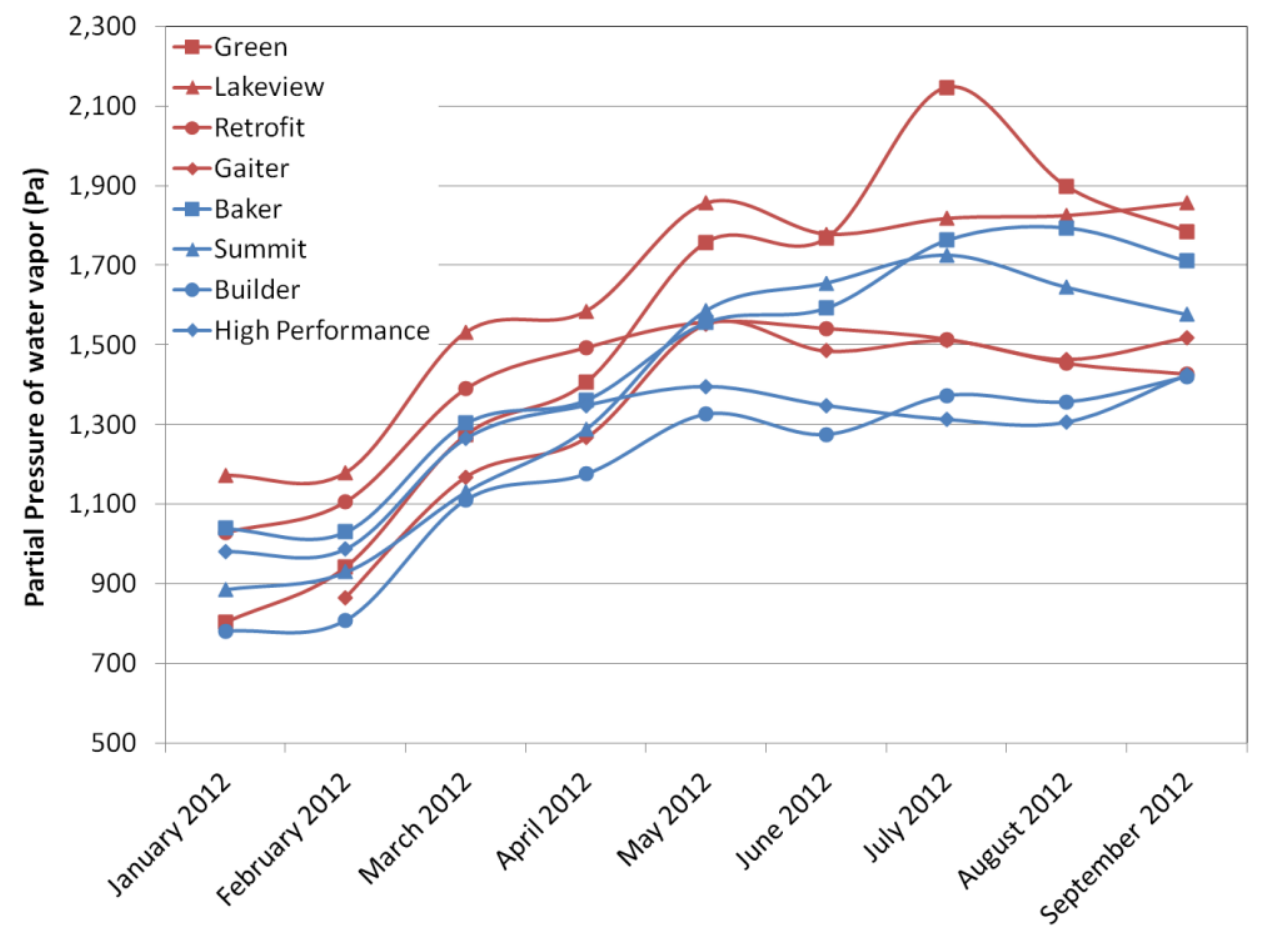

Fig. 5. The monthly average interior moisture levels for each home in the study between January 2012 and September 2012 (red: sealed; blue: vented). 


\subsection{DIURNAL VARIATION IN HUMIDITY}

In the unoccupied research homes, temperature and humidity sensors help us understand how vapor flows around the home. Figure 6 shows the $\mathrm{p}_{\mathrm{v}}$ curves of data collected during three sunny summer days (May 28-30, 2013) at all of the sensor locations shown in Fig. 2 in the retrofit home.

- the black curve represents $\mathrm{p}_{\mathrm{v}}$ under the roof deck,

- orange is midway through the open-cell foam,

- green is at the interface between the open-cell foam and the attic air,

- red is the attic air,

- brown is the interior of the home, and

- grey is the outside air.

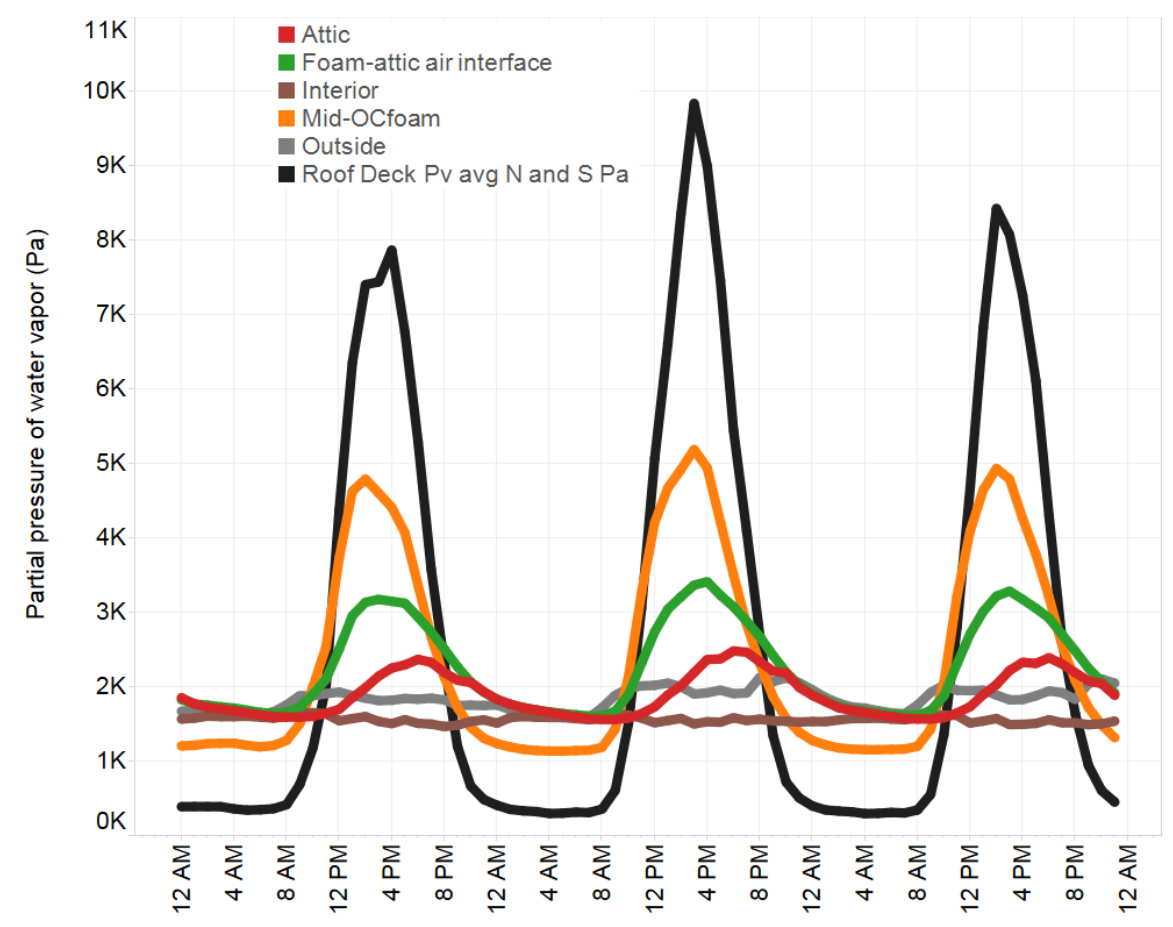

Fig. 6. Partial pressure of water vapor $\left(p_{v}\right)$ at measurement locations throughout the attic and interior of the sealed attic home for three sunny summer days. The black curve is $p_{v}$ under the roof deck, orange is midway through the open cell foam, green is at the interface between the open cell foam and the attic air, red is the attic air, brown is the interior of the home, and grey is the exterior condition.

When the sun was out, the $\mathrm{p}_{\mathrm{v}}$ under the roof deck (black) was higher than it was in the attic air (red). This shows the potential for water vapor flow by diffusion from the roof deck into the attic. During the day as the roof deck heats up, liquid moisture in the porous wood vaporizes. This vapor moves from areas of high vapor pressure to low vapor pressure. Since the attic has a lower vapor pressure vapor moves from the roof deck to the attic air. Also, during the night the attic $\mathrm{p}_{\mathrm{v}}$ was greater than the roof deck $\mathrm{p}_{\mathrm{v}}$; this 
shows the potential for water vapor flow from the attic back toward the roof deck. During the night, water vapor from the attic air is reabsorbed into the cool roof deck. Notice that the attic $p_{v}$ rose above the outdoor $\mathrm{p}_{\mathrm{v}}$ during the day; this suggests that there was a source adding moisture to the attic other than the exterior, which was likely the roof deck. For these three days the attic $\mathrm{p}_{\mathrm{v}}$ was equal to or above the interior $p_{v}$, but for many days throughout the year the attic $p_{v}$ fell lower than the interior $p_{v}$ during the early morning hours. This seems to depend on how much solar insolation hit the roof during the day, the more solar insolation the higher the attic $p_{\mathrm{v}}$ the following morning. Similarly, during a sunny winter day, the roof deck and attic vapor trends were similar: both rose during the day. During cloudy or rainy days, the roof sheathing $\mathrm{p}_{\mathrm{v}}$ did not rise much and usually did not get above the attic $\mathrm{p}_{\mathrm{v}}$ since the roof deck temperature did not rise significantly.

The material properties of the roof assembly and ceiling between the attic and interior were known, and the boundary conditions on either side of the assemblies were measured. We used the WUFI ${ }^{\circledR}$ heat and moisture transport software (Fraunhofer IBP 2013) to calculate the actual diffusive vapor flux and thus to understand vapor flow. We did not consider the roof rafters or holes in the ceiling when computing total vapor transport. Also, because the air pressure difference between the attic and interior was measured, we were able to compute the advective moisture movement. The flow rate described in Eq. (1) was used to compute the advective moisture flow, where $Q$ is the flow rate in cubic feet per minute (CFM), $C$ is the dimensionless air leakage coefficient, $\Delta P$ is the air pressure difference in pascals between the attic and interior and $n$ is the dimensionless pressure exponent.

$$
Q[c f m]=C \Delta P^{n}
$$

A guarded blower door test was used to determine the flow through the attic floor for a given pressure differential. $C$ was found to be 102.4 and $n$ was 0.675 . The volume flow rate was converted to a mass flow rate (kilograms per hour) using the water vapor concentration of the air moving across the attic floor plane.

Figure 7 shows the water vapor flow by diffusion and advection in the retrofit home for the same three days shown in Fig. 6. As will be the convention in this paper, a negative value means the flow direction is down (i.e., from the roof to the attic or from the attic to the interior). During the day, the roof deck adds moisture by diffusion to the attic, and during the night, the attic adds moisture back to the roof deck (shown in the blue curve). This phenomenon has been colloquially referenced as a "diurnal ping-pong," because the moisture bounces back and forth between the roof deck and the attic each day. We define "ping-pong" technically as back-and-forth movements of moisture across a building interface, typically driven by a thermally induced vapor concentration gradient. The orange curve shows the diffusion of water vapor across the attic floor. During those three days, the vapor flow is from the attic to the interior and is strongest during the afternoon and early nighttime hours. The red curve shows the advection across the attic floor. Although the curve is noisy, the general trend is that during the day the air flows from the attic to the interior and during the night from the interior to the attic. 


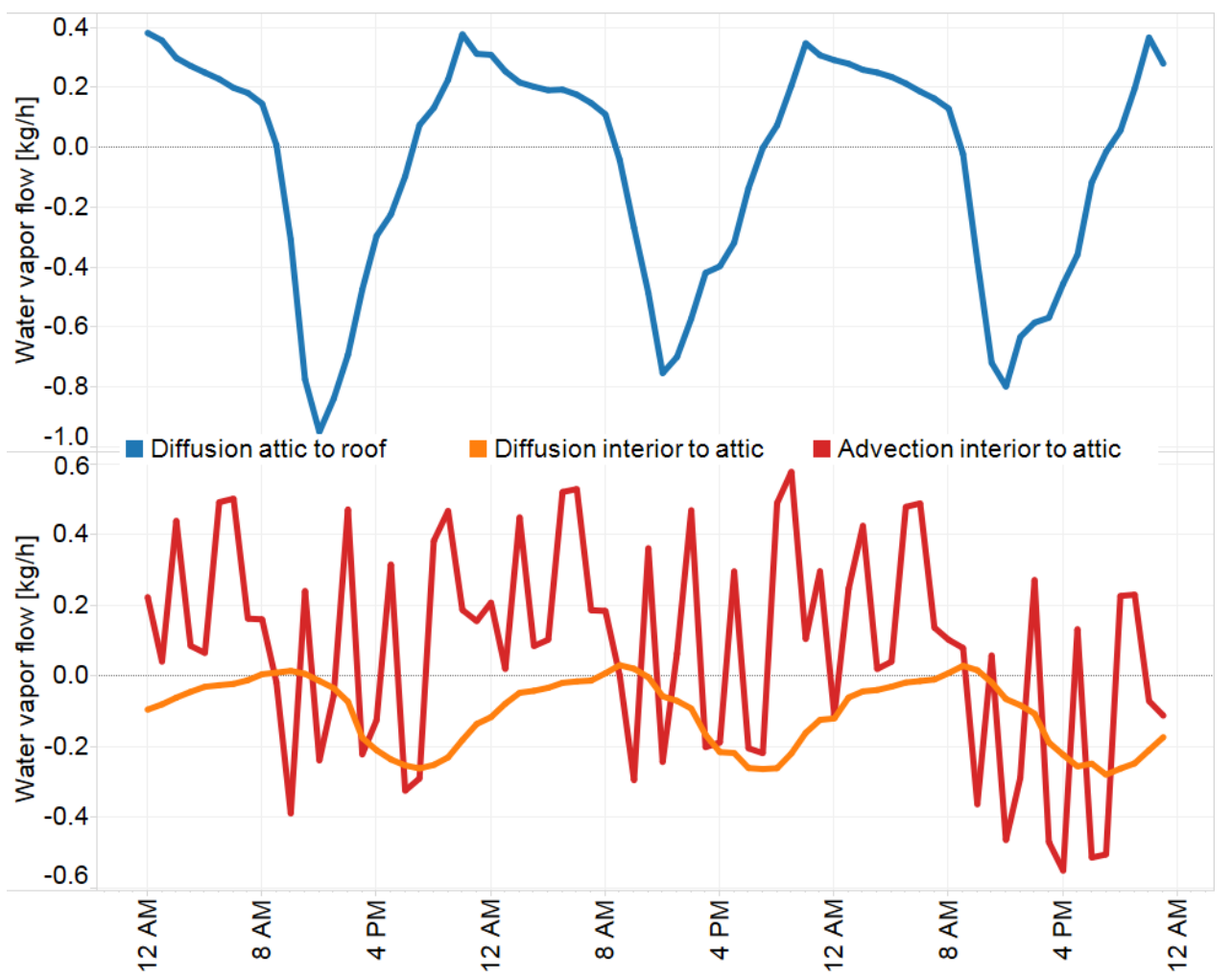

Fig. 7. Actual vapor flows in the sealed attic home. The blue curve shows diffusion from the attic to roof. Positive means the flow is from the attic to the roof sheathing. The orange curve is the diffusion from the interior to the attic. Positive means the flow is from the interior to the attic. The red curve is the convective vapor flow (advection) across the attic floor. Positive means the vapor is moving from the interior to the attic.

\subsection{SEASONAL VARIATION IN HUMIDITY}

Figure 8 shows the monthly average absolute moisture of the outside, under the roof sheathing, attic, and interior for the sealed attic home. The lower half of the plot shows the difference between the attic and roof absolute humidity and between the interior and attic absolute humidity. (The same sign convention used in Fig. 7 is used here.) The orange line in the lower plot of Fig. 8 show the difference between the interior and attic $\mathrm{p}_{\mathrm{v}}$. At no time was the sealed attic less humid than the interior (i.e., the orange line is negative). 


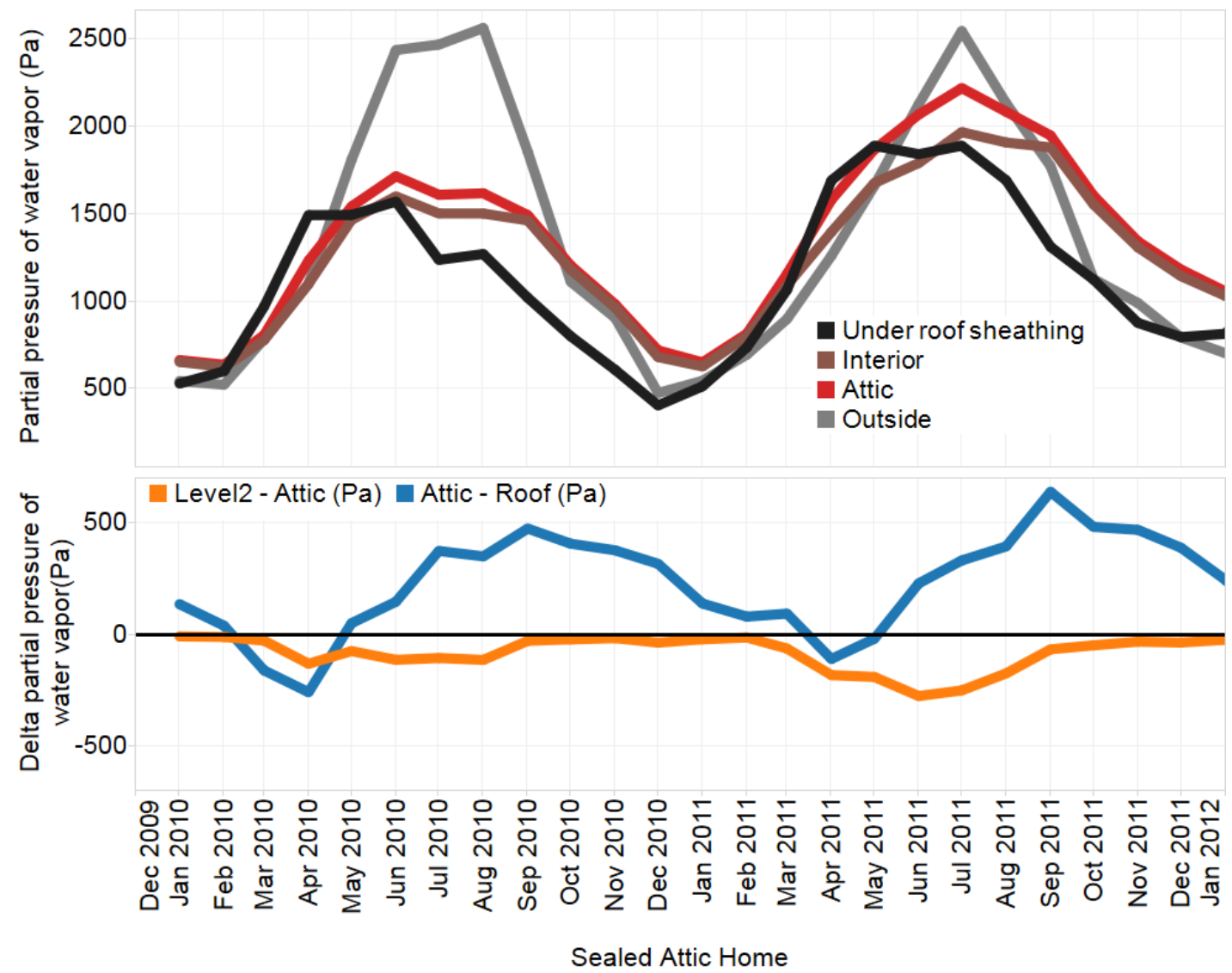

Fig. 8. Monthly average partial pressure of water vapor. The black curve is the average $\mathrm{p}_{\mathrm{v}}$ under the north and south roof deck, red is the attic air, brown is the interior of the home, and grey is the outdoor $\mathrm{p}_{\mathrm{v}}$. On the lower plot the difference in partial pressure of water vapor is shown for the attic to the roof and for the interior to the attic. If the curve is negative, that means the diffusive flow of water vapor is down (i.e., toward the inside of the home from the attic or toward the attic from the roof deck).

Figure 9 shows the actual net monthly vapor flows for the retrofit home. They correspond well to the delta pressure plots in Fig. 8. Figure 9 also shows the net monthly advective moisture flow across the attic floor when the measurements where available. That flow is larger than the two diffusive flows shown. Unfortunately, the pressure difference across the attic floor was not measured before May 2013. However, the available data suggest that the air flow is consistent with the stack effect and reverse stack effect: during the summer the air flow is from the attic to the interior, and during the winter the air flow should be from the interior to the attic. In a vented attic house during the winter, the stack effect would allow the interior to dry into the attic and escape through the attic vents; however, when the attic is sealed, the interior moisture cannot escape through the attic vents.

The blue curve in Fig. 9 suggests a seasonal ping-pong of moisture between the roof deck and the attic which is not observed in the vented attic home. During the summer to early winter, vapor from the attic is added to the roof sheathing. During the late winter to early summer months, vapor from the roof sheathing is added to the attic. The net diffusion of water vapor is from the attic to the roof deck in 2010 and 2011 and from the roof deck to the attic in 2012 and 2013 due to the variable capacity heat pump controlling for humidity. One caveat to keep in mind when the attic is compared with the interior for both diffusive and convective moisture transfer is that only one sensor was available to characterize the moisture levels. For example, the researchers noticed by using a thermal camera in the attic that warm 
moist air entered the attic from around the bathroom vents when the upstairs shower was running. Although the shower caused the interior humidity measurement to rise, some of the moisture flowed directly to the attic and bypassed the moisture sensor located in the hallway, thereby hindering the characterization by the hallway sensor of all moisture transport into the attic.

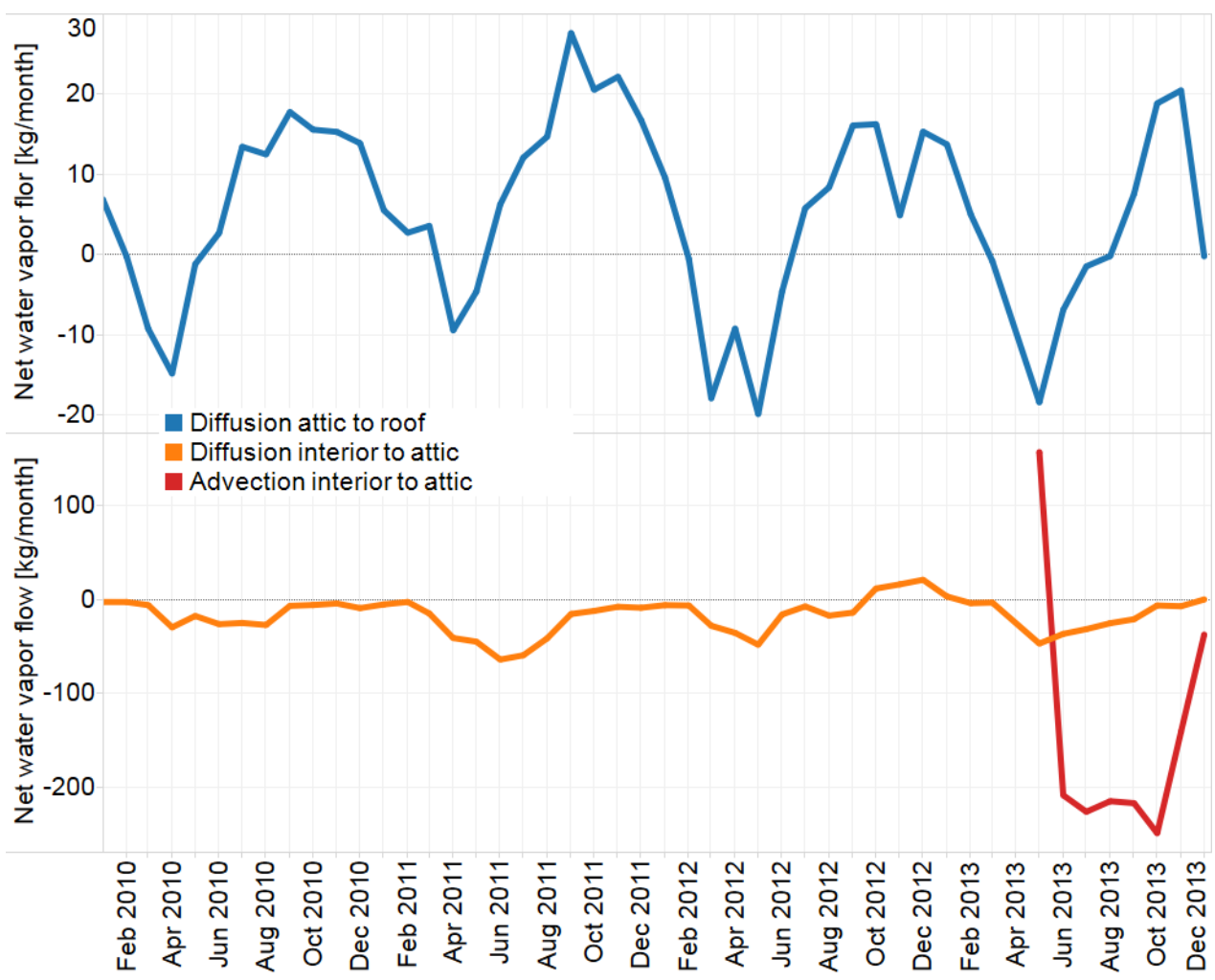

Fig. 9. Actual vapor flows in the sealed attic home. The blue curve shows diffusion from the attic to roof. Positive means the flow is from the attic to the roof sheathing. The orange curve is the diffusion from the interior to the attic. Positive means the flow is from the interior to the attic. The red curve is the convective vapor flow (advection), across the attic floor. Positive means the vapor is moving from the interior to the attic.

Figure 10 shows the moisture content of the north roof deck at the retrofit home calculated using WUFI® and helps us in understanding why the sealed attics are more humid than the vented attics. During the winter as the stack effect moves humid air into the attic the wood sheathing absorbs moisture from this humid air since it cannot escape to the outside. Figure 10 shows that between September and February the roof sheathing moisture content increases. As summer approaches and the solar insolation increases the roof sheathing moisture content decreases as this stored moisture is desorbed and added to the attic air. Since the summer reverse stack effect brings attic air into the home this will add moisture to the interior. So there are at least two contributing non-mechanical phenomenon to the sealed attic's higher moisture. The first is the lack of venting and the second is the storage of moisture in the roof sheathing that acts as a capacitor for moisture. The roof deck stores moisture during the winter to release it back into the attic during the summer. 


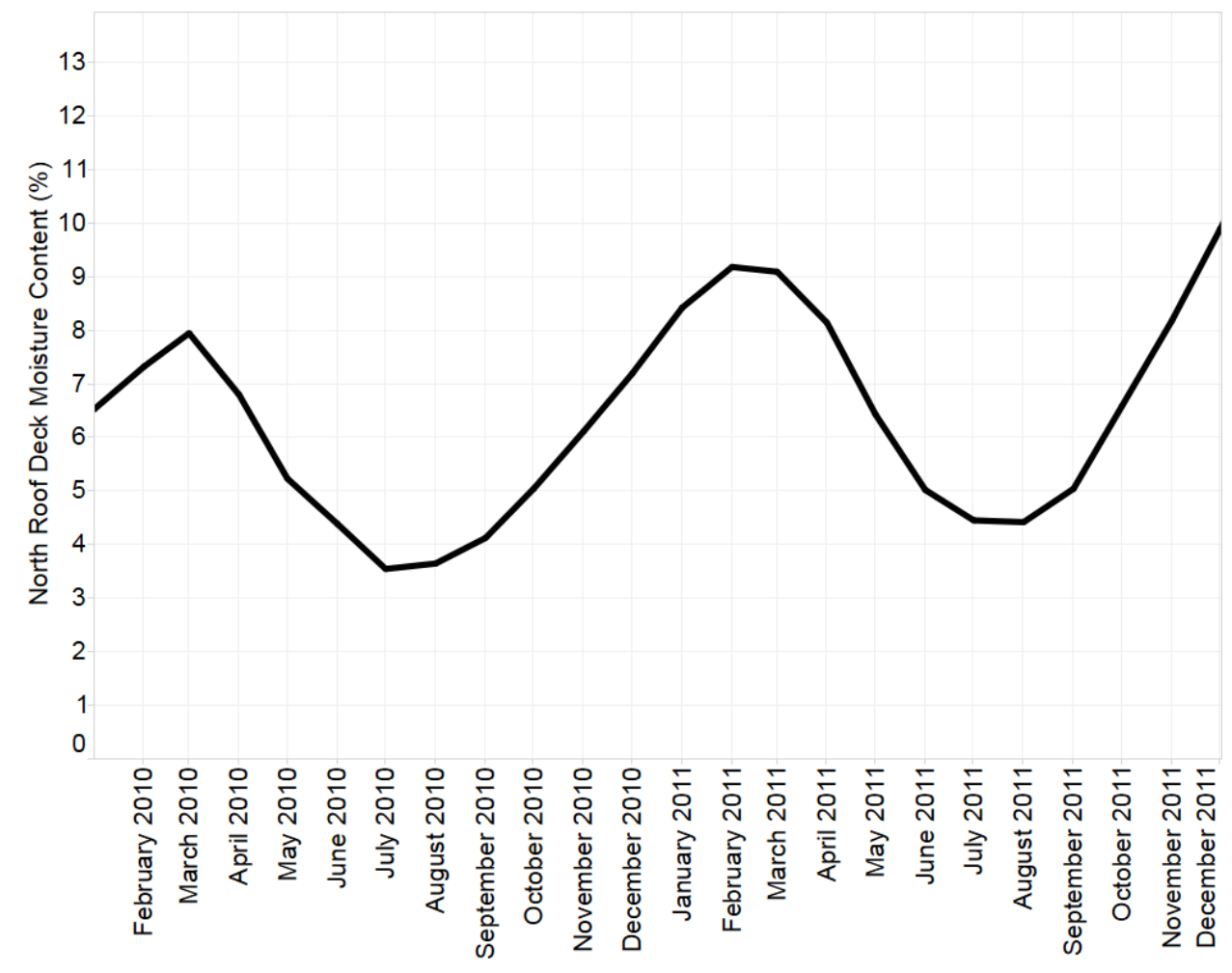

Fig. 10. Moisture content of the north roof sheathing at the retrofit home.

\subsection{SEALED ATTIC MOISTURE SOURCES}

Above we have presented the general trends observed in attic and interior moisture levels of sealed and vented attic homes in the mixed-humid climate and described the diurnal and seasonal ping-pong of moisture between the roof deck and attic at the sealed attic research home. We have also discussed the moisture movement by diffusion and advection between the interior and the attic, namely that diffusion typically moves water from the attic to the interior but that advection dominated the moisture movement across the attic floor plane. Advection brings attic air into the interior during the summer and from the interior to the attic during the winter. Because the attic vents are foamed over in the sealed attic home and air cannot escape from the attic easily, winter advection into the attic adds moisture to the roof deck to be stored throughout the winter. When the longer summer days come with more solar insolation the stored moisture is desorbed into the attic making it more humid. During the summer since advection is from the attic to the interior the sealed attic can contribute to higher moisture levels in the home. Coupled with the fact that sealed attics reduce sensible cooling loads in the home without impacting internal sources of moisture generation (e.g. cooking, showers, etc), the SHR in the home can be significantly decreased if no additional moisture mitigation measure is taken.

Now we will discuss in more detail the physics behind the roof sheathing to attic moisture transfer and how the exterior effects the attic environment. The major potential water and vapor transport mechanisms for an attic are presented in Fig. 11. Another possible moisture transport mechanism presented in Fig. 11 is capillary suction, which will depend on the features of the roof shingles and their surface properties. We will discuss this further below. 


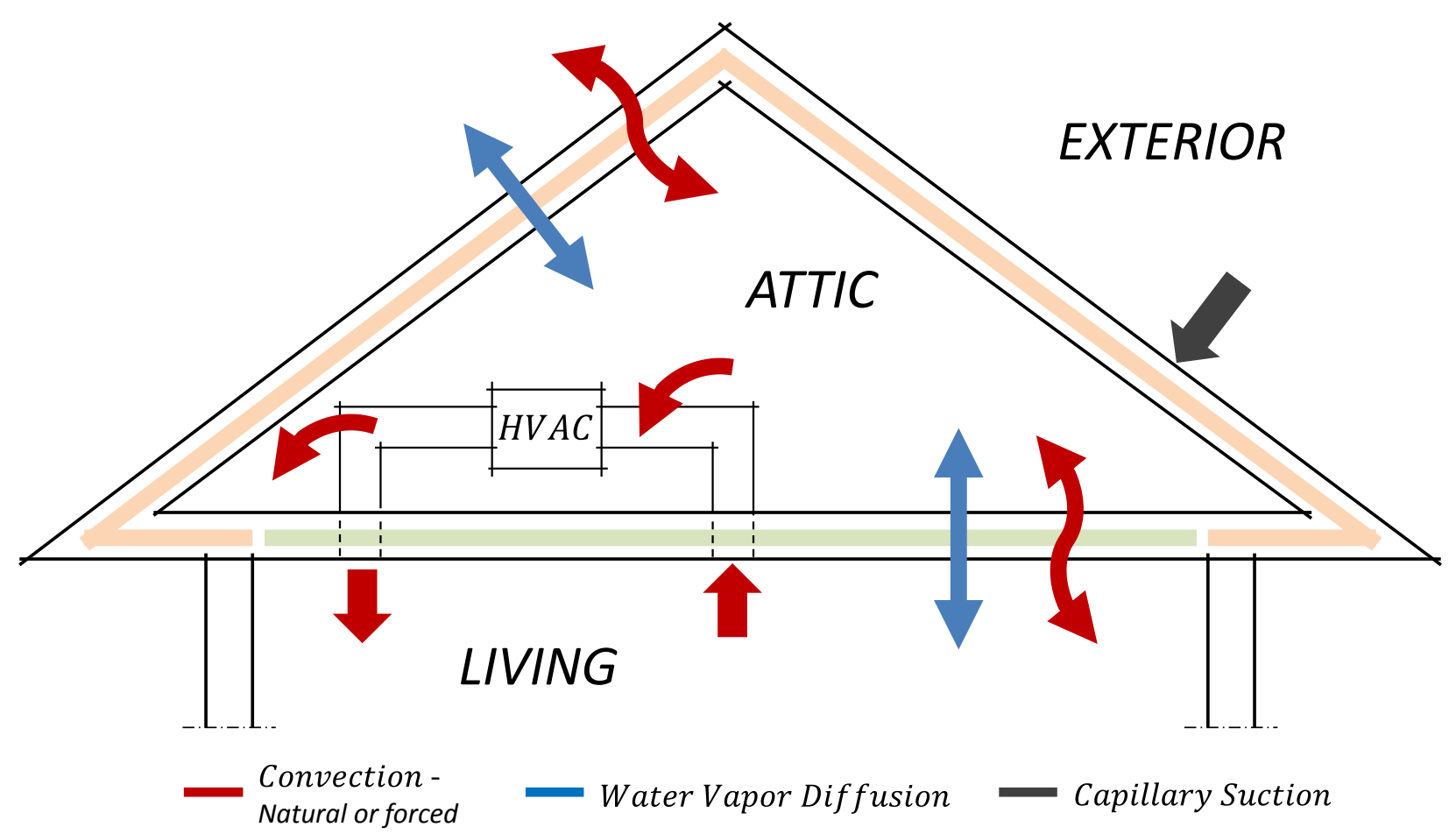

Fig. 11. Potential water and vapor transportation mechanisms and locations in an attic and roof. The colors of the arrows depict the type of moisture transportation. Further, the roof and the ceiling planes are also provided with colors to emphasize the boundaries between the interior, the attic, and the exterior environments.

\subsubsection{Roof Sheathing}

The diurnal nature of the measured humidity under the roof deck and in the attic was shown in Fig. 6. The increase in humidity was not seen on cloudy or rainy days, when the temperature of the roof deck rose very little. The diurnal increase in measured water vapor is very well correlated with the temperature of the roof deck. Wood absorbs or desorbs water vapor depending on the temperature of the environment that it is in. The sorption isotherms of wood are described in the Wood Handbook and explain what is causing the diurnal variation in humidity seen under the roof deck (FPL 2010). As the roof deck heated during the day, the wood desorbed water vapor into the space between the roof deck and foam. The humidity sensor measured the water vapor as it was desorbed. Because the attic had less absolute moisture, the water vapor under the roof sheathing diffused through the foam into the attic. When the roof began to cool off, it reabsorbed the remaining moisture that was underneath the roof deck. At night, the attic (because it had a higher humidity than under the roof deck) moved moisture up to the roof deck by diffusion through the foam. This is the diurnal or short-term ping-pong of water vapor. The same phenomenon seen in the roof sheathing is also expected to occur with all the wood in the attic as the attic environment changes throughout the day, and the wood will respond by trying to reach equilibrium moisture content with its environment.

For the summer through the early winter the net vapor flow was from the attic to the roof deck, which means the moisture content of the roof deck was rising during that time. For other parts of the year, the net flow was from the roof deck to the attic, so the roof deck moisture content was decreasing from the late winter through the early summer. This is seen in the blue curve in Fig. 9 and in Fig. 10. Figure 10 shows the seasonal or long-term ping-pong of moisture between the roof sheathing and the attic. 


\subsubsection{Solar-driven moisture}

Some have speculated that solar-driven moisture might explain or contribute to the diurnal variation in attic humidity (Parker 2005, BSC 2003, and Rudd 2005). The solar driven moisture mechanism is not well defined in literature, so we will define and access the mechanism here. Solar-driven moisture is believed to be caused by liquid water condensing on top of the roof on days when dew is likely. This water finds its way between the shingles by capillary forces and then causes the air underneath the shingles to increase in humidity, possibly reaching saturation. When the sun rises and hits the roof, the temperature of the roof rises, enabling a higher water vapor pressure in the air layer because air at higher temperatures can hold more vapor and the water between the shingle laps is readily available to be evaporated into this air layer. Due to a gradient of water vapor concentration, the potential for water vapor diffusion between the air layer and the underlying roof materials is created. This is described in Fig. 12. The likelihood of solar-driven vapor diffusion in a roof assembly is discussed in the following analysis.

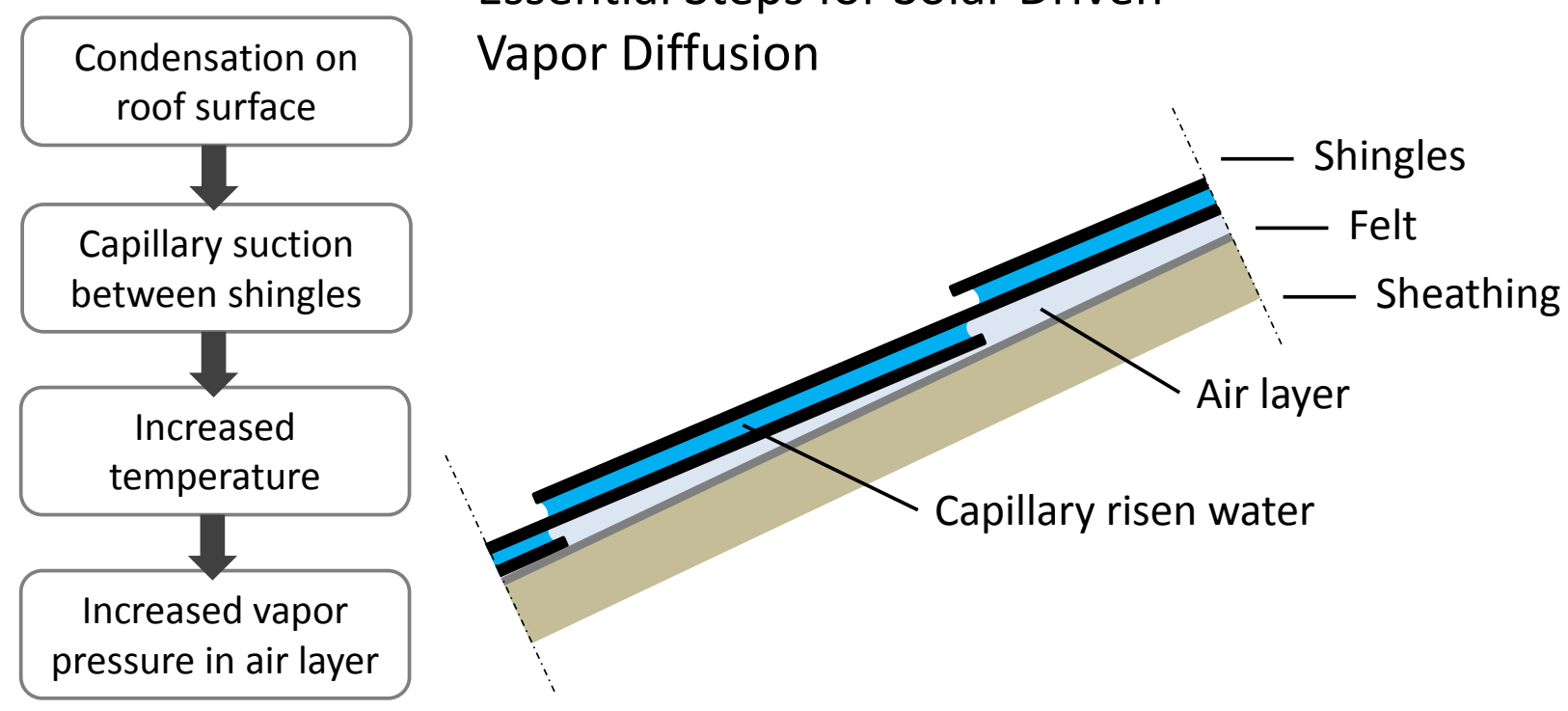

Fig. 12. There are four essential steps for solar-driven water vapor diffusion in asphalt shingle roofs. These steps are presented in the left section of the figure and the assembly of roof materials is illustrated to the right.

As seen in Fig. 12, condensation on the roof surface is the first essential step for solar-driven vapor diffusion, which may occur if the surface temperature is below the exterior dew-point temperature. The cooling effect from the exchange of long-wave radiation between the roof surface and the sky exists mainly during a night when the sky is clear and the winds are calm. This scenario may lower the surface temperature of the roof to a favorable point for condensation. The south roof surface temperature of the retrofit home began being measured on May 20, 2013. Since that day until December 6, 2013, 180 of the 201 days had at least 3 hours a night where the roof temperature was below the outdoor dew point temperature.

The next essential step for solar-driven vapor diffusion is for the condensed water to be transported between the laps of the shingles by an assumed capillary force. For the likelihood of such a transport 
mechanism to be evaluated, the capillarity of the physical shingle assembly needs to be determined. Equation (2) describes the suction height, $H$, due to capillarity (Hens 2007):

$$
H=\frac{2 \cdot \sigma \cdot \cos \theta}{g \cdot d \cdot \rho_{\text {water }}}
$$

where $\sigma$ is the surface tension coefficient, $\theta$ is the contact angle between the shingle surface and the water meniscus, $g$ is the acceleration of gravity, $\rho_{\text {water }}$ is the density of water, and $d$ is the width between the shingles. Figure 13 shows a graphic describing the physical parameters. The width between the shingles is the most decisive variable in this equation as it is not known. In general, $\theta$ can be assumed to equal zero (Hagentoft 2001). After the known variables are inserted, the simplified expression of the suction height becomes Eq. (3):

$$
H=\frac{2.4 \cdot 10^{-2}}{d}(\text { inch })
$$

According to Fig. 13, the suction height, $H$, which is also the required height to fully saturate the lap distance between the shingles, will depend on the slope of the roof. Therefore, a maximum width between the shingles can be estimated for different slopes of the roof. Assuming the width of a shingle sheet to be a $1 \mathrm{ft}$ length roughly results in an overlap length of $6 \mathrm{in}$. Based on this assumption, together with a given slope of the roof, both $H$ and $d$ can be estimated, as presented in Table 3. The slope of the roof will determine the required suction height to enable water to fill the lap between the shingles with water by capillary suction. The maximum width to maintain capillary suction between the shingles is estimated for the roof slopes of $3: 12,4: 12,8: 12$, and 12:12. The maximum width between the shingles, $d$, is remarkably small to allow for successful capillarity

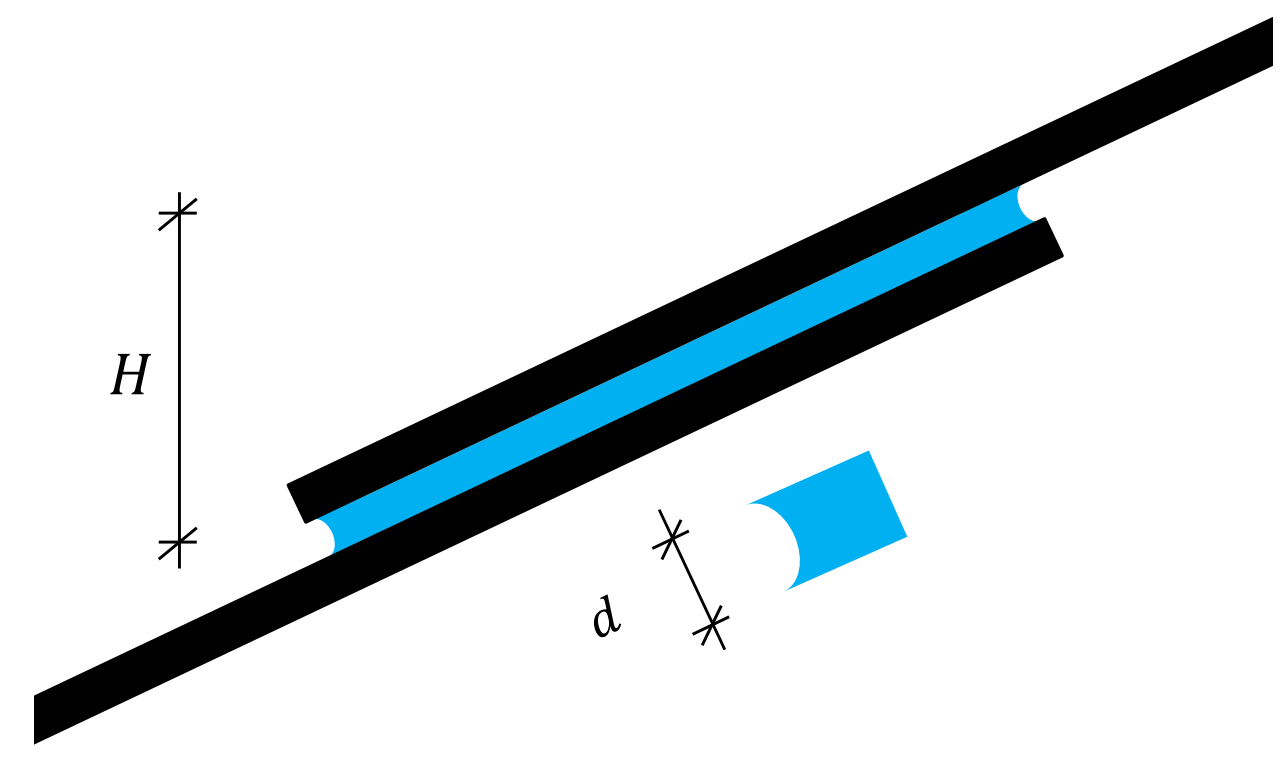

Fig. 13. An illustration of the suction height, $H$, and the width between the shingle sheets, $d$. 
Table 3. Summary of roof slope, capillary height, and maximum capillary width ${ }^{a}$.

\begin{tabular}{lcccc}
\hline Roof slope & $3: 12$ & $4: 12$ & $8: 12$ & $12: 12$ \\
Capillary height, $\boldsymbol{H}$ (in.) & 1.46 & 1.90 & 3.33 & 4.24 \\
Maximum width, $\boldsymbol{d}$ (in.) & $\leq 1 / 60$ & $\leq 1 / 80$ & $\leq 1 / 140$ & $\leq 1 / 180$ \\
\hline
\end{tabular}

${ }^{a}$ Assumes a $1 \mathrm{ft}$ shingle width and an overlap of 6 in.

As seen in Table 3, the maximum width to allow for capillary suction between the shingle sheets is very small. This maximum width, $d$, must not be exceeded; otherwise, the suction pressure will drop and a complete filling of the interface will not exist. In addition, the shingles are usually designed with an adhesive strip, as illustrated in Fig. 14. This strip will most likely act as a dam to block liquid water from moving through the lap, but even if it does not block water, the strip is likely to be thicker than the maximum lap width for capillarity. Given these factors, it is unlikely that solar-driven moisture can occur in this way. Further rationale for the limited existence of solar-driven moisture is discussed below.

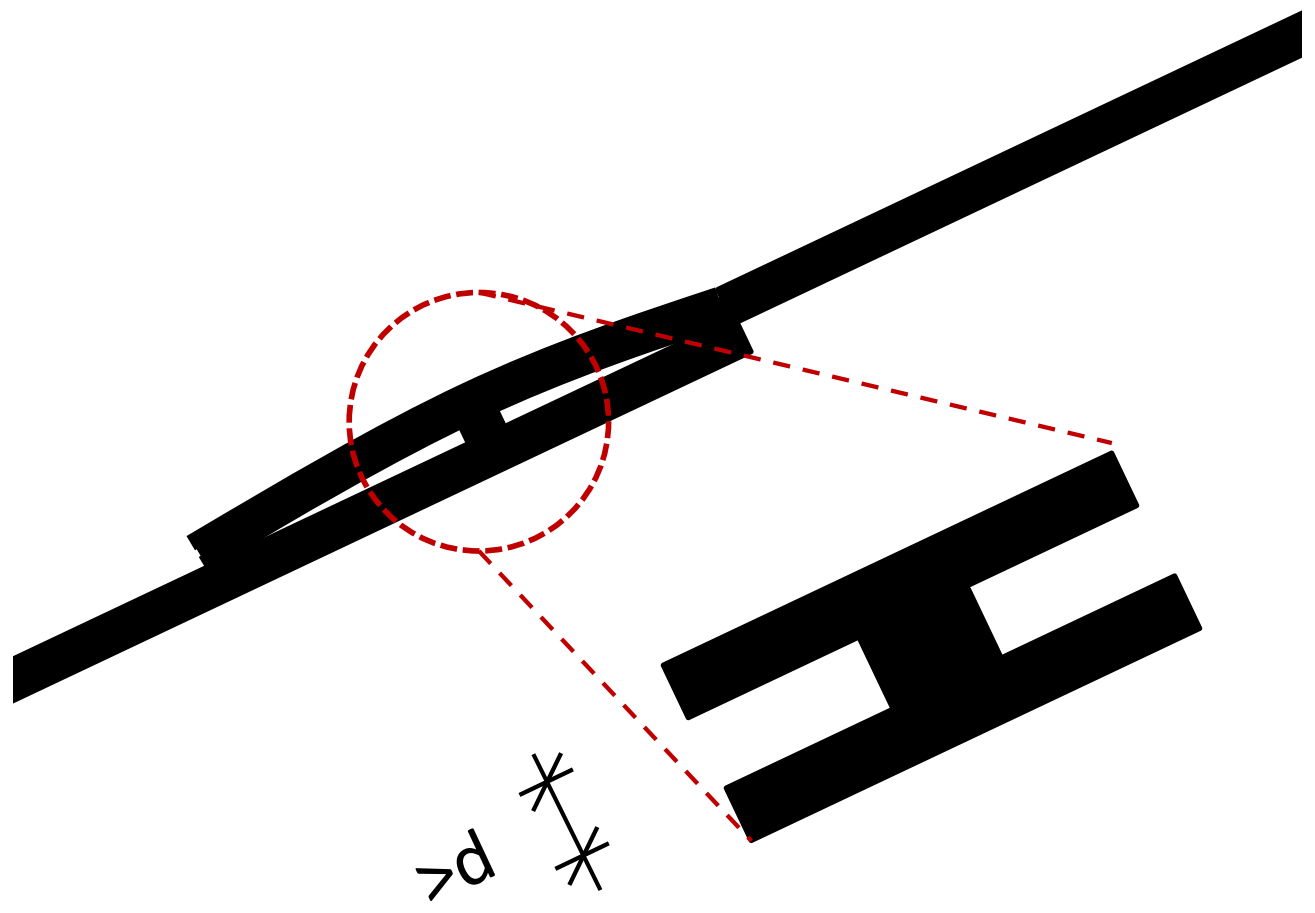

Fig. 11. The adhesive strip between the shingle sheets is likely to prevent capillary suction of water into the interface of the shingles because the required maximum width, $d$, is likely to be exceeded.

There are four essential steps for solar-driven vapor diffusion to exist in asphalt roof shingles, as shown in Fig. 12. Even though capillary suction has been proven unlikely, the third and fourth step will still be investigated. Naturally, there are no doubts that the temperature will increase when the sun hits the roof surface; however, whether the air layer between the shingles and the sheathing is close to or fully saturated with water vapor is investigated below. 
A two-dimensional simulation model was created in WUFI®2D, in accordance with Fig. 15. In order to establish the most favorable scenario for solar-driven vapor diffusion, the lap between the shingles was assumed to be completely saturated with water at all times. The purpose was to study the effect on the $\mathrm{p}_{\mathrm{v}}$, and thus the relative humidity, in the air layer underneath the shingles, and also the effect on the moisture content of the wood sheathing. The measured climate from the weather station at the unoccupied research houses was used as the exterior climate and the interior boundary conditions were based on measurements from underneath the retrofit home attic sheathing. Two simulations were performed; one with an assumed saturated interface between the shingles and one without any water between the shingles.

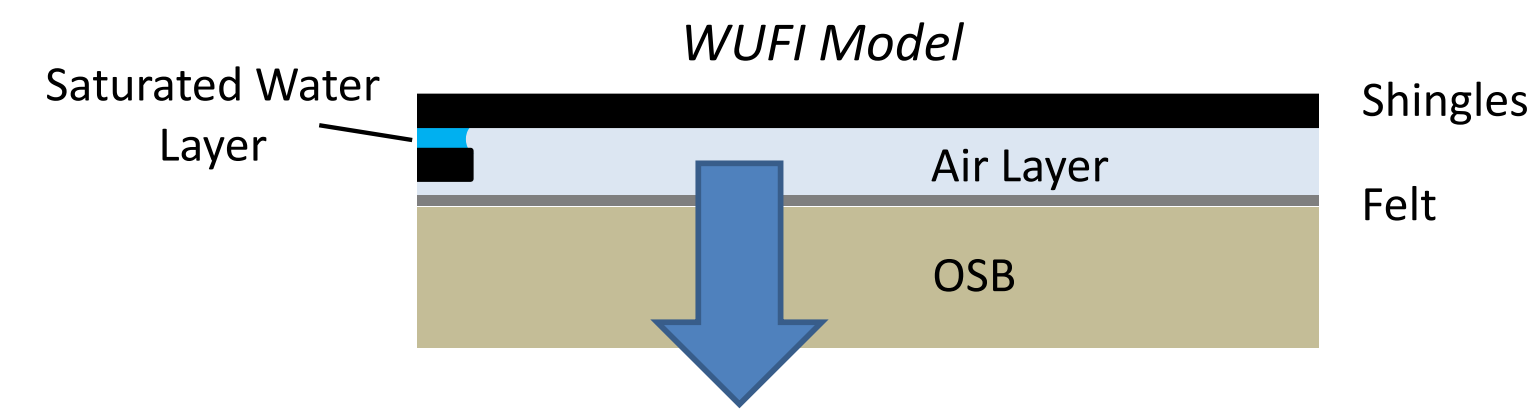

Fig. 15. A two-dimensional model was created in WUFI $® 2 D$ to simulate an asphalt shingle roof assembly. A moisture source was added to the left side of the air layer, representing the assumed saturated shingles interface. Two simulations were executed, one with the moisture source, and one without. The arrow indicates the possible direction of water vapor diffusion.

The case assuming a humid air layer between the shingles and underlayment (felt) also simulates the situation where the shingles might let humid air pass to the air space between the shingles and underlayment. This scenario would assume that the shingles are breathable and that the adhesive strip is not airtight.

The results from the simulations are presented in Figs. 16 and 17. The air layer thickness was assumed to $1 / 25$ in. 


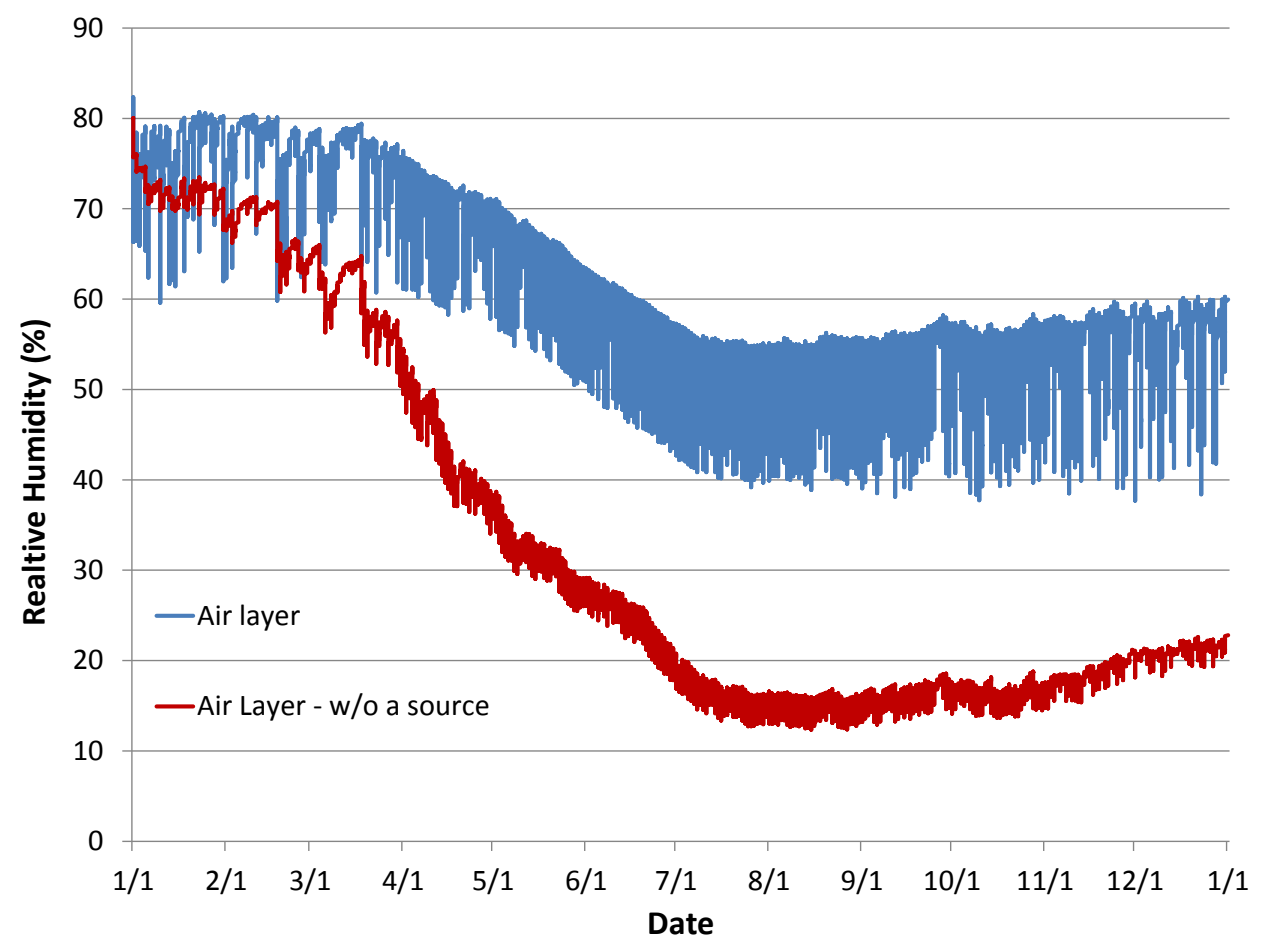

Fig. 16. The annual variation in relative humidity of the air layer underneath the shingles with and without an assumed constantly saturated shingles interface. The result is based on simulations using a two-dimensional simulation model.

The $\mathrm{p}_{\mathrm{v}}$ increases in the air layer with the existence of the water-saturated shingle interface. However, this increase is not sufficiently large to make a significant impact on the moisture content of the roof underlayment. According to Fig. 17, the moisture content of the wood sheathing only increases slightly by the existence of a constant liquid-water-saturated shingle lap. In conclusion, significant solar-driven vapor diffusion through asphalt roof shingles is unlikely because the capillary force is determined to be insufficient to drive substantial amounts of water all the way through the shingle laps. Even if the water reached the sheathing its impact on the moisture content of the sheathing would not be significant compared with the impact of the moisture in the attic environment. 


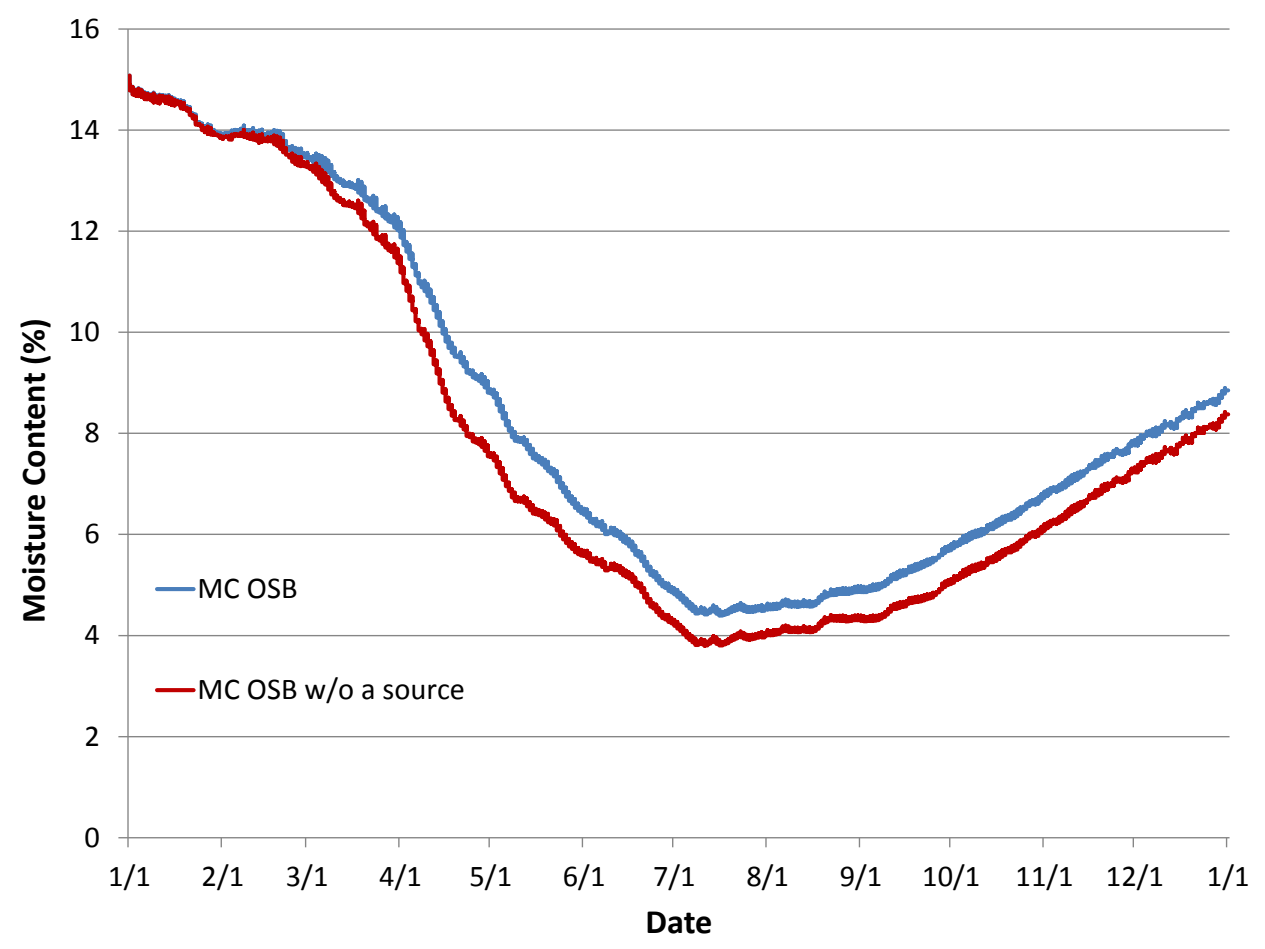

Fig. 12. The annual variation of moisture content in the wood sheathing with and without an available moisture source between the shingle laps. The simulation results indicate that this moisture source only has a slight impact on the sheathing moisture content.

\subsubsection{Exterior}

Sealed attics are in general much less connected to the outside environment than vented attics. This does not mean however that the sealed attic is perfectly isolated from the outside. There is expected to be some connection of the attic to the outside although it will be much smaller than the connection of a vented attic. A guarded blower door measurement was performed on the retrofit home and supported this conclusion, showing 336 CFM@50Pa of leakage through the roof. This is about 23\% of the whole house infiltration, which was measured to be 1443 CFM@50Pa (Salonvaara et al. 2013). Based on the LBL effective leakage area, the whole house leakage area is $77 \mathrm{in.}^{2}$ (Sherman and Dickerhoff 1998). This amounts to about 18 in. $^{2}$ of leakage area in the sealed attic roof. This means that there is some amount of outside air infiltration/exfiltration between the sealed attic and exterior.

Evaluating how outside air infiltration affects the sealed attic moisture performance will depend on the climate zone. If the home is in a dry climate, then some sealed attic infiltration might not hinder the attic's moisture performance and may actually help dehumidify the attic and therefore the interior space. In a humid climate, sealed attic infiltration could negatively impact the attic's moisture performance. Because the test homes are in the mixed-humid climate, during the summer the outside air usually has a higher $p_{v}$ than the attic. Because there is usually a reverse stack effect, the attic would suck outside air into the attic and doing so would effectively humidify the attic. Figure 18 illustrates this with $p_{v}$ in the four sealed attics compared with the outdoor $\mathrm{p}_{\mathrm{v}}$. During the winter, the stack effect would cause attic exfiltration, which would bring interior air into the attic. The interior is usually less humid than the attic, so the winter stack effect would dehumidify the attic. 


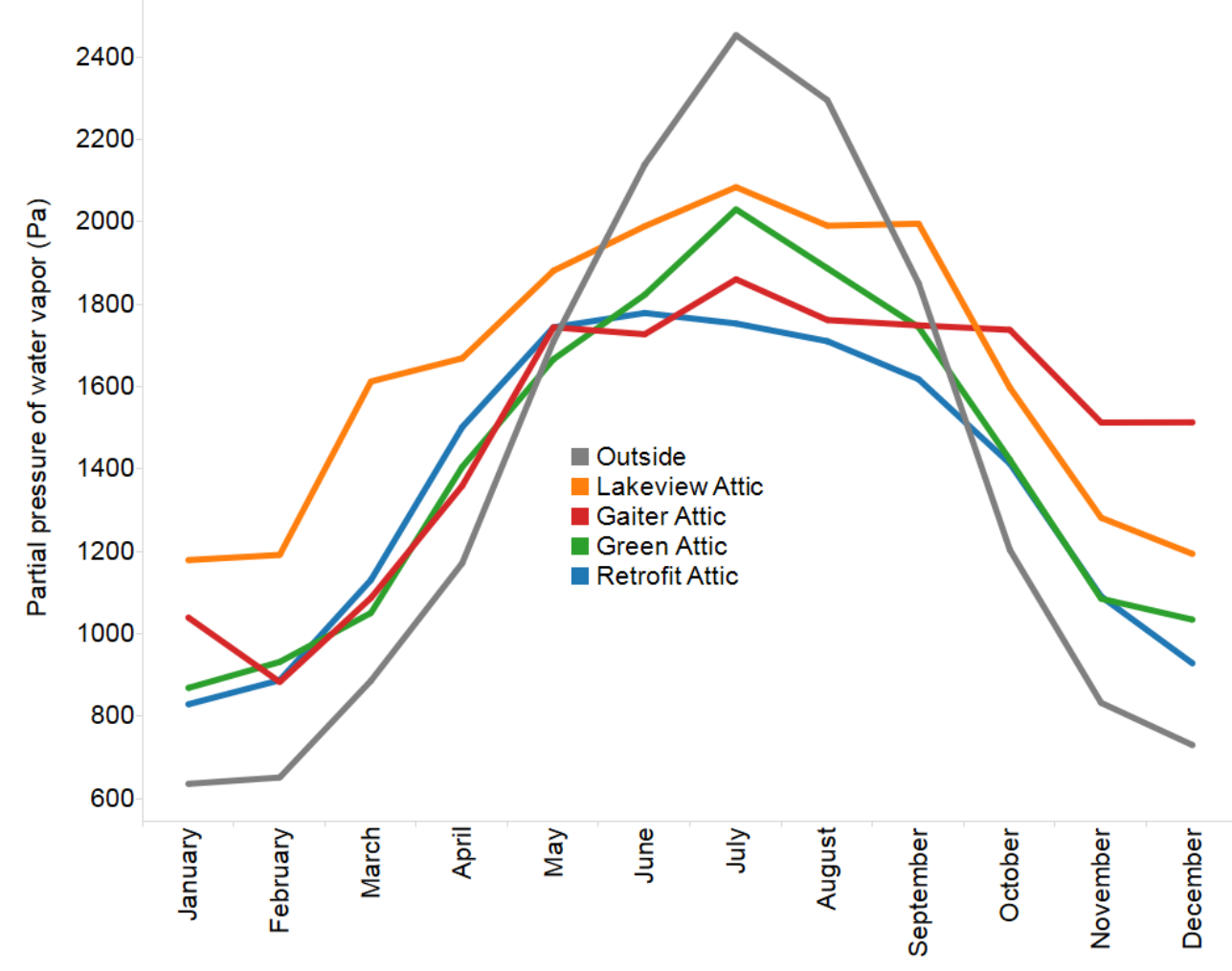

Fig. 1813. Monthly average absolute humidity in the sealed attics compared with the outside humidity.

\subsection{COMFORT}

In general we observed higher interior humidity in sealed attic homes compared to vented attic homes. This was seen in the retrofit house compared to the builder and high performance house, which is a good comparison because the homes have the same occupant density (see Table 2) and are operated at the same interior temperature set points. Figure 19 shows the difference in interior relative humidity between the retrofit home and the builder home. During the summer, the sealed attic home has 5\% to $15 \%$ higher humidity than the vented attic home (both homes were maintained at $76^{\circ} \mathrm{F}$ ). This humidity level was high enough that many people complained about the "stickiness" of the sealed attic home after leaving the builder home. Furthermore, an indicator of a high-performance house is that it is comfortable. If the sealed attic as an energy conservation measure makes the interior "sticky" then we should revisit whether it is a suitable measure to bring ducts into the conditioned space in the mixed-humid climate. 


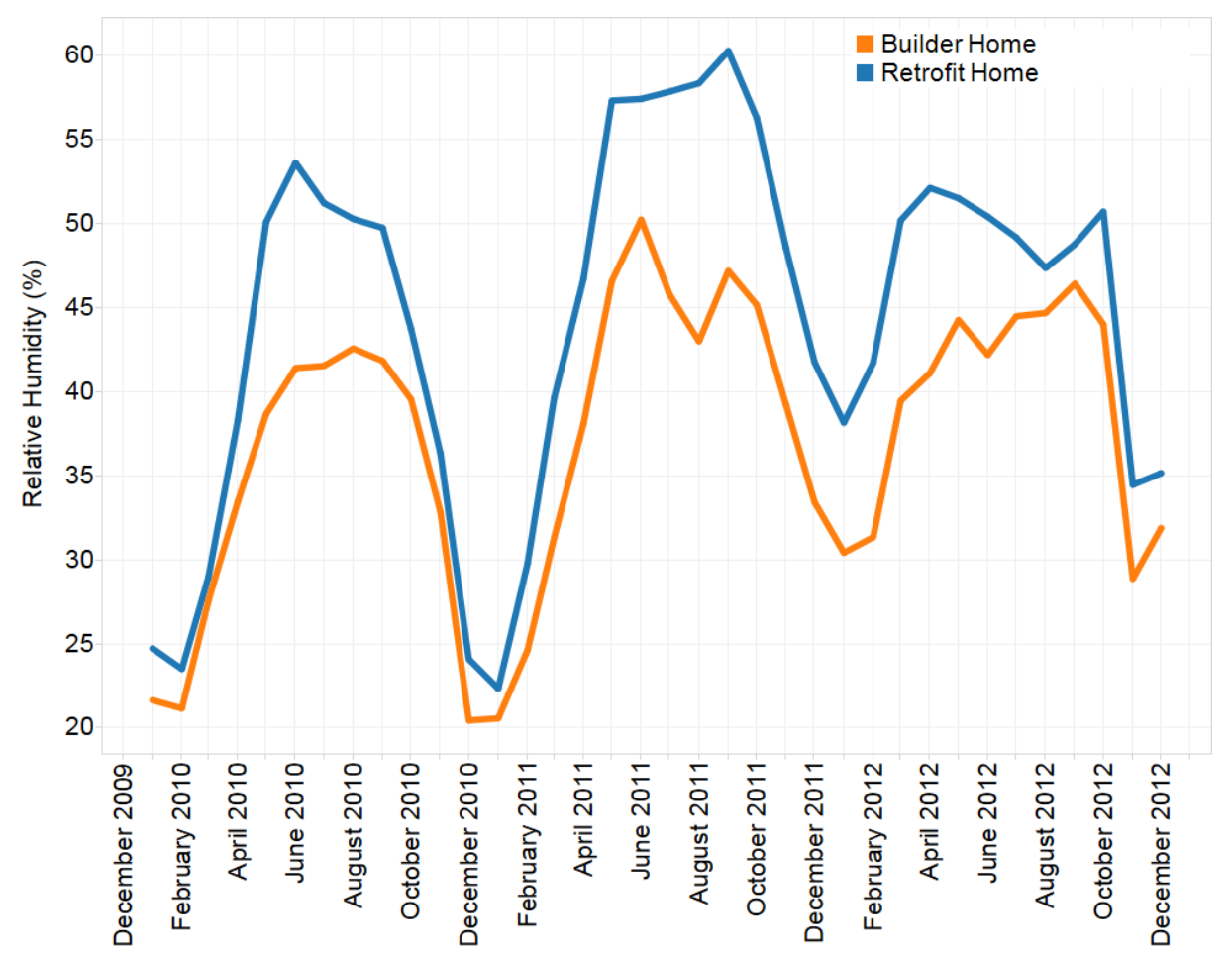

Fig. 19. Monthly average relative humidity for the interior of the retrofit home (sealed attic) compared to the builder home (vented attic).

\subsection{DURABILITY}

There was no evidence of material degradation and minimal mold potential in the last 4 years at the retrofit home. ASHRAE 160 guidelines were used to determine whether there was any potential for mold at the north or south roof decks (ASHRAE 2009). The southern-facing roof had no potential for mold growth using the 24-hour, 7-day and 30-day performance criteria; however, for the north roof the 30-day performance criterion was not met for a period of time. During the winter of 2011/2012 for a period of about 50 days the 30-day moving average relative humidity was above $80 \%$; however, the 7-day and 24hour criteria were met. It is believed this was due to the high vapor concentration in the attic that was caused by a combination of the sealed attic and not using the attic ducts while the ductless multi-split system was in operation. A section of foam was removed from both the north and south roofs in March 2013. The roof deck measured less than $10 \%$ moisture content (M.C.) at both locations, and there was no visual indication of OSB degradation. Figure 11 shows the estimated monthly average moisture content of the north roof sheathing for about 3 years. The roof sheathing stays under $20 \%$ M.C., which is a good indication that there was low potential for roof sheathing decay (FPL 2010).

\subsection{ENERGY CONSUMPTION}

We have already determined that the higher interior moisture in the sealed attic home has not affected the durability of the building materials so far; however, it does seem that the sealed attic can increase the humidity inside a home in the mixed-humid climate, if no additional moisture mitigation measure is taken. Both the lack of attic venting and the storage of moisture in the roof sheathing that adds a capacitance for holding moisture during the winter and releasing it in the summer contributes to higher attic humidity. During the summer when the reverse stack effect brings attic air into the interior, this released moisture is added back to the living space. The sealed attic can also affect the ability of the HVAC system to dehumidify during the summer as well, further contributing to high interior moisture. 
Since the sealed attic lowers the sensible heat load of the home, the HVAC will not have as long a runtime and therefore exhibit a reduced ability to dehumidify during the summer. In order to not diminish interior comfort levels in the home due to higher humidity, additional energy consumption will be required to meet remaining latent loads. Even if additional measures to mitigate moisture are not taken, a higher interior relative humidity will cause the HVAC system to operate with a lower sensible heat ratio (SHR) because more energy is being used to condense the moisture in the air as it travels over the coils. If the HVAC system could not control the interior humidity then the homeowner would likely lower the thermostat set point to increase comfort.

Multiple approaches exist to mitigate higher moisture levels in attics, which include providing conditioned air to the attic. Because the laboratory home had a variable speed HVAC system with the ability to adjust the equipment sensible heat ratio (SHR) closer to the building's (SHR), the higher moisture level in the home was reduced by controlling the humidity. The variable-capacity heat pump had two modes of operation: efficiency mode and comfort mode. The comfort mode can be used to control the relative humidity of the interior of the home to a user-determined set point. During the summer of 2012, the variable-capacity heat pump was put in comfort mode with a relative humidity set point of $46 \%$, which was close to the humidity inside the builder and high performance homes. The effect of this can be seen in the retrofit home relative humidity during June, July, and August 2012 (see Fig. 19). The measured seasonal energy efficiency ratio of the system decreased 8\%, from 18.7 to 17.2 (Munk et al. 2013). When the HVAC system was controlling relative humidity, its energy consumption increased. The heat pump energy was compared to the outdoor air temperature, and two linear regressions were computed for each of the different heat pump modes. Figure 20 shows the results. Equations (4) and (5) show the linear regressions of the daily heat pump cooling energy as a function of the average daily outdoor temperature.

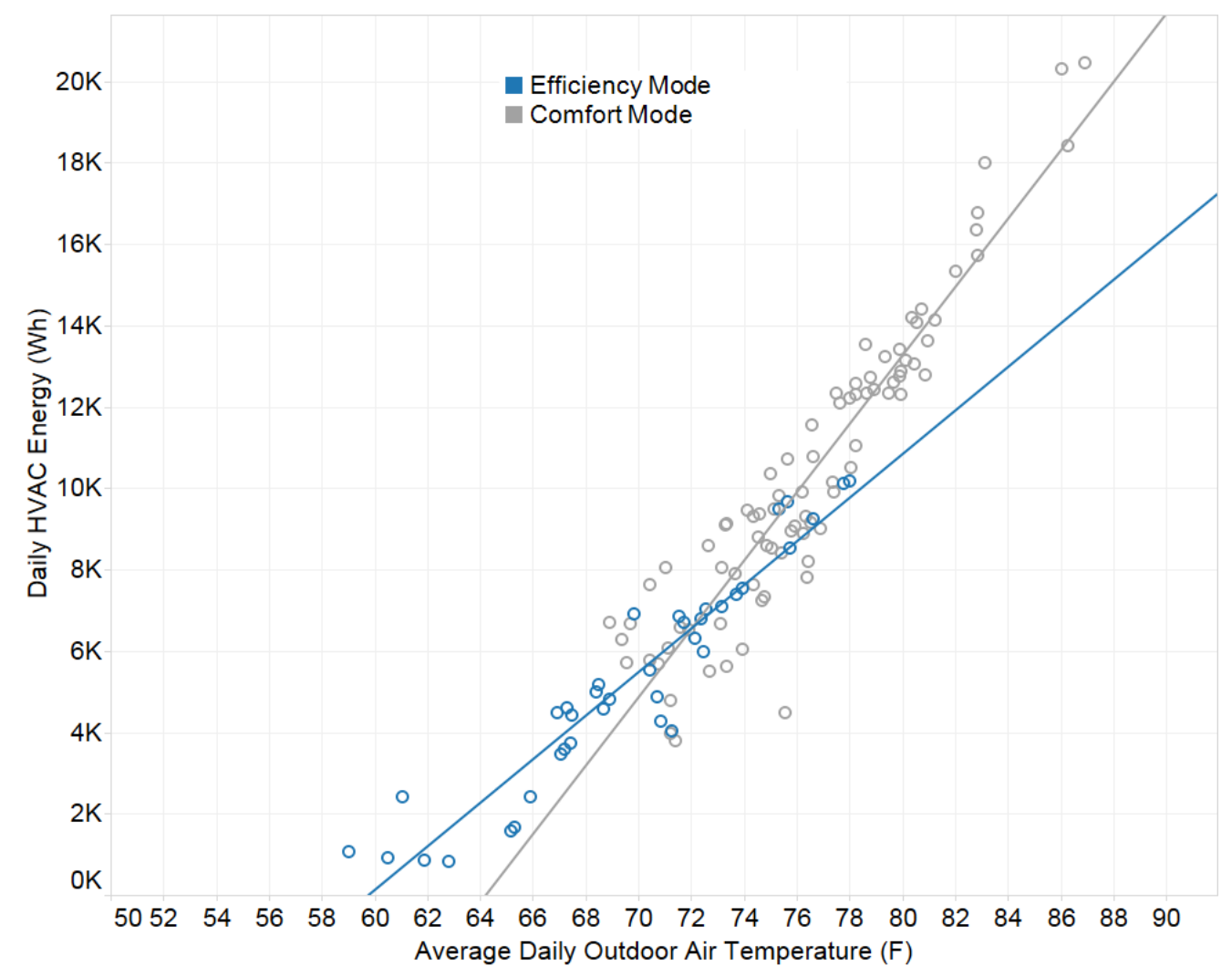

Fig. 20. Heat pump energy vs average daily outdoor air temperature. 


$$
\begin{gathered}
E_{d}^{\text {comfort }}=840 T_{d}-53962 \\
E_{d}^{\text {efficiency }}=536 T_{d}-32025
\end{gathered}
$$

Equation (4) is applicable when the heat pump is in comfort mode, where it controls based on a relative humidity set point. Equation (5) is applicable when the heat pump is in efficiency mode. Cooling-season (May 1-August 31) TMY3 data for Knoxville, Tennessee, was input into each of these regressions and it was found that when in comfort mode the energy consumption of the HVAC system increased by $7 \%$.

The cost of the sealed attic in the retrofit house was about $\$ 5900$ (Christian et al. 2010). A sealed attic, however, is only one way of bringing ducts into the conditioned space. In new construction, ducts can be brought into the interior conditioned space for $\$ 0.4$ to $\$ 0.5$ per square foot with an estimated savings of $8 \%$ to $15 \%$ on space-conditioning bills (DOE 2013b). For a $2400 \mathrm{ft}^{2}$ home, this amounts to $\$ 960$ to $\$ 1200$, so for new construction in the mixed-humid climate, it can be more cost effective to bring ducts into the conditioned space with careful air sealing and insulation and by cleverly designed chases or by putting ducts in the interstitial space rather than by using a sealed attic. This solution also avoids possible humidity issues that could come with the sealed attic. For existing homes, the solution for bringing ducts into the conditioned space is not as easy. Well-insulated, buried ducts could be an alternative solution (Shapiro et al. 2013). 


\section{CONCLUSION}

Oak Ridge National Laboratory studied eight homes in the mixed-humid climate to better understand the moisture performance of the sealed attic. Four were sealed attic homes, and four were vented attic homes. We observed that, on average, the sealed attic homes had both higher attic moisture levels and higher interior moisture levels than the vented attic homes. This can be attributed in part to the fact that sealed attics reduce sensible cooling loads in the home without impacting internal sources of moisture generation (e.g. cooking, showers, etc). Therefore, the sensible heat ratio (SHR) in the home is decreased. If this SHR is much lower than the equipment SHR, higher interior moisture levels in the sealed attic home could result if no additional moisture mitigation measure is taken.

Additionally, excess moisture that enters a vented attic can be removed via the ridge vents. However, it was found in the homes studied that this drying mechanism is hindered in the sealed attic because the soffit, gable, and ridge vents have been sealed with foam, thereby minimizing ventilation to the exterior. Instead of the moisture entering the attic being vented out, it is absorbed during the winter by the roof sheathing and other wood in the attic to be released back in the home during the summer. This effect also further decreases the SHR in the home. An extensive analysis of a simulated-occupancy laboratory home with an unvented attic was conducted to better assess the infiltration and exfiltration of attic moisture. Because solar driven moisture through the roof deck is often speculated as a source of moisture infiltration, physics-based analysis was used to elucidate this phenomenon and to suggest it provides very limited, if any at all, contribution to the moisture level in the home.

We also identified a diurnal and seasonal ping-pong of water vapor between the roof deck and sealed attic. Attic materials such as the roof sheathing and other wood members store moisture to be absorbed and released on diurnal or seasonal rhythms. The seasonal ping-pong between the roof deck and the attic is only observed in the sealed attic home. Despite the higher attic and interior moisture in the sealed attic, so far there is no indication of mold or material degradation.

ORNL also found that to control the humidity in the sealed attic home to levels closer to a similar unoccupied, vented attic home increased the cooling energy consumption by $7 \%$. This reduced the estimated $10 \%$ space-conditioning energy savings expected with the sealed attic energy conservation measure. Therefore, sealed attics may not be a cost-effective way to bring ducts into semiconditioned spaces in the mixed-humid climate.

Further research can be done in other climate zones to see whether sealed attics have the same effect on the interior as in the mixed-humid climate. Also the current hygrothermal properties of roof assembly materials are not known at in situ conditions. Current properties are typically assessed at standard temperature and pressure (Lstiburek 2011). It is not known how a roof assembly responds to varying levels of relative humidity when a roof experiences the typical thermal fluctuations. Roof sheathing temperatures range from $10^{\circ} \mathrm{F}$ to $160^{\circ} \mathrm{F}$ throughout the year. Thus it is necessary to know the properties of a roof assembly at different temperatures to correctly estimate and model vapor diffusion through or in it.

Other research needs to be done to understand how the condition of the attic floor (air leakage and thermal resistance) affects the moisture performance of the sealed attic. As was discussed in this report, the way the interior interacts with the sealed attic affects the humidity in the attic. This interaction studied in different climate zones can help us understand the sealed attic moisture performance across the United States. 



\section{REFERENCES}

Aldrich, R., L. Arena, D. Griffiths. S. Puttagunta, and D. Springer. 2010. The Consortium of Advanced Residential Buildings (CARB) - A Building America Energy Efficient Housing Partnership. Report OSTI ID: 1031549, Steven Winter Associates, Inc. USA.

ASHRAE, 2009. ANSI/ASHRAE Standard 160-2009 Criteria for Moisture-Control Design Analysis in Buildings. Atlanta: American Society of Heating, Refrigeration, and Air-Conditioning Engineers, Inc.

Boudreaux, P., T. Gehl, and J. Christian. 2012a. Occupancy Simulation in Three Residential Research Houses. ASHRAE Transactions 118:625-37.

Boudreaux, P., K. Biswas, and R. Jackson. 2012b. Advancing Residential Retrofits in the Mixed-humid Climate to Achieve Deep Energy Savings: Final Report on Knoxville, TN Homes. Report ORNL/TM-2012/533, Oak Ridge National Laboratory, USA.

BPI. 2005. Building Performance Institute Technical Standards for the Building Analyst Professional. Malta, New York: Building Performance Institute, Inc.

BSC. 2003. Unvented Roofs, Hot-Humid Climates, and Asphalt Roofing Shingles. Report 0306, Building Science Corporation, USA.

Christian, J., T. Gehl, P. Boudreaux, J. New, and R. Dockery. 2010. Tennessee Valley Authority's Campbell Creek Energy Efficient Homes Project: 2010 First Year Performance Report July 1, 2009August 31, 2010. Report ORNL/TM-2010/206, Oak Ridge National Laboratory, USA.

Colon C. 2011. New Construction Builders Challenge: Sealed Attic and High Efficiency HVAC in Central Florida: A Year in Review. Report FSEC-PF-454-11, Florida Solar Energy Commission, USA.

DOE. 2013a. Building America Top Innovations Hall of Fame Profile: Unvented, Conditioned Attics. http://apps1.eere.energy.gov/buildings/publications/pdfs/building_america/ 1_1c_ba_innov_unventedconditionedattics_011713.pdf

DOE. 2013b. Building America Top Innovations Hall of Fame Profile: Ducts in Conditioned Space. http://apps1.eere.energy.gov/buildings/publications/pdfs/building_america/1_1g_ba_innov_ductscond itionedspace_011713.pdf

FPL. 2010. Wood Handbook-Wood as an Engineering Material. Report FPL-GTR-190. United States Department of Agriculture Forest Service, USA.

Fraunhofer IBP. 2013. WUFI®2D, Version 3.3. Fraunhofer Institute of Building Physics. Germany.

GBA. 2010. High humidity issues in a spray foam attic. http://www.greenbuildingadvisor.com/ community/forum/general-questions/17488/high-humidity-issues-spray-foam-attic

Hagentoft, C. 2001. Introduction to Building Physics. Lund, Sweden: Studentlitteratur.

Hens, H. 2007. Building Physics Heat, Air and Moisture - Fundamentals and Engineering Methods with Examples and Exercises. Chapter 2.4, Moisture Transfer. Berlin: Ernst \& Sohn.

Jackson, R., E. Kim, S. Roberts, and R. Stephenson. 2012. Advancing Residential Retrofits in Atlanta. Report ORNL/TM-2012/488, Oak Ridge National Laboratory, USA.

JLC. 2010. Moisture issue in an unvented attic...... http://forums.jlconline.com/forums/ showthread.php?52456-Moisture-issue-in-an-unvented-attic..... 
Lstiburek, J., A. Karagiozis, and P. Gassman. 2011. Vapor permeability provides no performance benefit for roofing underlayments in ventilated attics. http://www.rci-online.org/interface/2011-12Lstiburek,\%20Karagiozis,\%20Gassman.pdf

Munk, J., C. Halford, and R. Jackson. 2013. Component and System Level Research of Variable Capacity Heat Pumps. Report ORNL/TM-2013/36, Oak Ridge National Laboratory, USA.

Parker, D. 2005. Literature Review of the Impact and Need for Attic Ventilation in Florida Homes. Report FSCE-CR-1496-05, Florida Solar Energy Commission, USA.

Rose, W. 1995a. Early History of Attic Ventilation. Building Research Council—School of Architecture, University of Illinois at Urbana-Champaign

Rose, W. 1995b. The History of Attic Ventilation Regulation and Research. Proceedings of the Buildings VI Conference. Clearwater Beach, FL.

Rudd, A., J. Lstiburek, P. Eng, and Kohta Ueno. 1999. Unvented-Cathedralized Attics: Where We've Been and Where We're Going. Report 9904, Building Science Corporation, USA.

Rudd, A. 2005. Field Performance of Unvented Cathedralized (UC) Attics in the USA. Journal of Building Physics 29(2):145-169.

Salonvaara, M., A. Karagiozis, A. Desjarlais. 2013. Moisture Performance of Sealed Attics in Climate Zones 1 to 4. Thermal Performance of the Exterior Envelope of Whole Buildings XII International Conference. Clearwater Beach, FL.

Shapiro C., A. Magee, and W. Zoeller. 2013. Reducing Thermal Losses and Gains with Buried and Encapsulated Ducts in Hot-Humid Climates. Report, Steven Winter Associates, USA.

Sherman, M., D. Dickerhoff. 1994. Air-tightness of US. Dwellings. Proceedings of $15^{\text {th }}$ AIVC Conference. Buxton, UK, 1:225-234. 